Cochrane Database of Systematic Reviews

\title{
Symptomatic treatment of the cough in whooping cough (Review)
}

Wang K, Bettiol S, Thompson MJ, Roberts NW, Perera R, Heneghan CJ, Harnden A

Wang K, Bettiol S, Thompson MJ, Roberts NW, Perera R, Heneghan CJ, Harnden A.

Symptomatic treatment of the cough in whooping cough.

Cochrane Database of Systematic Reviews 2014, Issue 9. Art. No.: CD003257.

DOI: 10.1002/14651858.CD003257.pub5.

www.cochranelibrary.com 
TABLE OF CONTENTS

HEADER 1

ABSTRACT

PLAIN LANGUAGE SUMMARY

BACKGROUND

OBJECTIVES

METHODS

RESULTS

Figure 1.

Figure 2.

DISCUSSION

AUTHORS' CONCLUSIONS

ACKNOWLEDGEMENTS

REFERENCES

CHARACTERISTICS OF STUDIES

DATA AND ANALYSES

Analysis 1.1. Comparison 1 Antihistamines versus placebo, Outcome 1 Paroxysms of cough per 24 hours.

Analysis 2.1. Comparison 2 Pertussis immunoglobulin versus placebo, Outcome 1 Mean paroxysmal cough per hour.

Analysis 2.2. Comparison 2 Pertussis immunoglobulin versus placebo, Outcome 2 Mean number of whoops per day (first week).

Analysis 2.3. Comparison 2 Pertussis immunoglobulin versus placebo, Outcome 3 Mean whoops per hour.

Analysis 2.4. Comparison 2 Pertussis immunoglobulin versus placebo, Outcome 4 Duration of hospital stay (days).

Analysis 3.1. Comparison 3 Salbutamol versus placebo, Outcome 1 Paroxysms of cough per day.

Analysis 4.1. Comparison 4 Steroids versus placebo, Outcome 1 Duration of hospital stay (days).

ADDITIONAL TABLES

APPENDICES

WHAT'S NEW

HISTORY

CONTRIBUTIONS OF AUTHORS

DECLARATIONS OF INTEREST

SOURCES OF SUPPORT

INDEX TERMS 
[Intervention Review]

\section{Symptomatic treatment of the cough in whooping cough}

Kay Wang ${ }^{1}$, Silvana Bettiol ${ }^{2}$, Matthew J Thompson³, Nia W Roberts ${ }^{4}$, Rafael Perera ${ }^{1}$, Carl J Heneghan ${ }^{1}$, Anthony Harnden ${ }^{1}$

1Nuffield Department of Primary Care Health Sciences, University of Oxford, Oxford, UK. 2Department of Medicine and Paramedicine, Faculty of Health, University of Tasmania, Hobart, Australia. ${ }^{3}$ Department of Family Medicine, University of Washington, Seattle, WA, USA. ${ }^{4}$ Bodleian Health Care Libraries, University of Oxford, Oxford, UK

Contact address: Kay Wang, Nuffield Department of Primary Care Health Sciences, University of Oxford, Radcliffe Observatory Quarter, Woodstock Road, Oxford, Oxon, OX26GG, UK. kay.wang@phc.ox.ac.uk.

Editorial group: Cochrane Acute Respiratory Infections Group.

Publication status and date: New search for studies and content updated (no change to conclusions), published in Issue 9, 2014.

Citation: Wang K, Bettiol S, Thompson MJ, Roberts NW, Perera R, Heneghan CJ, Harnden A. Symptomatic treatment of the cough in whooping cough. Cochrane Database of Systematic Reviews 2014, Issue 9. Art. No.: CD003257. DOI: 10.1002/14651858.CD003257.pub5.

Copyright @ 2014 The Cochrane Collaboration. Published by John Wiley \& Sons, Ltd.

\section{A B S T R A C T}

\section{Background}

Around 16 million cases of whooping cough (pertussis) occur worldwide each year, mostly in low-income countries. Much of the morbidity of whooping cough in children and adults is due to the effects of the paroxysmal cough. Cough treatments proposed include corticosteroids, beta2-adrenergic agonists, pertussis-specific immunoglobulin, antihistamines and possibly leukotriene receptor antagonists (LTRAs).

\section{Objectives}

To assess the effectiveness and safety of interventions to reduce the severity of paroxysmal cough in whooping cough in children and adults.

\section{Search methods}

We updated our searches of the Cochrane Central Register of Controlled Trials (CENTRAL, 2014, Issue 1), which contains the Cochrane Acute Respiratory Infections Group's Specialised Register, the Database of Abstracts of Reviews of Effects (DARE 2014, Issue 2), accessed from The Cochrane Library, MEDLINE (1950 to 30 January 2014), EMBASE (1980 to 30 January 2014), AMED (1985 to 30 January 2014), CINAHL (1980 to 30 January 2014) and LILACS (30 January 2014). We searched Current Controlled Trials to identify trials in progress.

\section{Selection criteria}

We selected randomised controlled trials (RCTs) and quasi-RCTs of any intervention (excluding antibiotics and vaccines) to suppress the cough in whooping cough.

\section{Data collection and analysis}

Two review authors (SB, MT) independently selected trials, extracted data and assessed the quality of each trial for this review in 2009. Two review authors (SB, KW) independently reviewed additional studies identified by the updated searches in 2012 and 2014 . The primary outcome was frequency of paroxysms of coughing. Secondary outcomes were frequency of vomiting, frequency of whoop, frequency of cyanosis (turning blue), development of serious complications, mortality from any cause, side effects due to medication, admission to hospital and duration of hospital stay.

\section{Main results}

We included 12 trials of varying sample sizes ( $N=9$ to 135), mainly from high-income countries, including a total of 578 participants. Ten trials recruited children ( $\mathrm{N}=448$ participants). Two trials recruited adolescents and adults $(\mathrm{N}=130$ participants). We considered only three trials to be of high methodological quality (one trial each of diphenhydramine, pertussis immunoglobulin and montelukast). Included studies did not show a statistically significant benefit for any of the interventions. Only six trials, including a total of 196 
participants, reported data in sufficient detail for analysis. Diphenhydramine did not change coughing episodes; the mean difference (MD) of coughing spells per 24 hours was 1.9; 95\% confidence interval $(\mathrm{Cl})-4.7$ to $8.5(\mathrm{~N}=49$ participants from one trial). One trial on pertussis immunoglobulin reported a possible mean reduction of -3.1 whoops per 24 hours $(95 \% \mathrm{Cl}-6.2$ to $0.02, \mathrm{~N}=47$ participants) but no change in hospital stay (MD - 0.7 days; $95 \% \mathrm{Cl}-3.8$ to $2.4, \mathrm{~N}=46$ participants). Dexamethasone did not show a clear decrease in length of hospital stay (MD -3.5 days; $95 \% \mathrm{Cl}-15.3$ to $8.4, \mathrm{~N}=11$ participants from one trial) and salbutamol showed no change in coughing paroxysms per day ( $\mathrm{MD}-0.2 ; 95 \% \mathrm{Cl}-4.1$ to $3.7, \mathrm{~N}=42$ participants from two trials). Only one trial comparing pertussis immunoglobulin versus placebo $(\mathrm{N}=47$ participants) reported data on adverse events: $4.3 \%$ in the treatment group (rash) versus 5.3\% in the placebo group (loose stools, pain and swelling at injection site).

\section{Authors' conclusions}

There is insufficient evidence to draw conclusions about the effectiveness of interventions for the cough in whooping cough. More highquality trials are needed to assess the effectiveness of potential antitussive treatments in patients with whooping cough.

\section{PLAIN LANGUAGE SUMMARY}

\section{Treatment of the cough in whooping cough}

\section{Review question}

We reviewed the evidence from 12 studies about the effect of treatments for cough in patients with whooping cough.

\section{Background}

We wanted to discover whether any medicines are effective at treating cough in patients with whooping cough (also known as pertussis). These medicines included pertussis immunoglobulin (antibodies to increase the body's resistance to whooping cough) and treatments already used to treat symptoms of asthma and hay fever (antihistamines, salbutamol, steroids). Patients with whooping cough may experience severe coughing bouts. These may be accompanied by whooping (the sound made when taking a deep breath in after coughing) and vomiting, which can lead to dehydration, difficulty breathing and being admitted to hospital. We aimed to find out whether any medicines are effective at reducing coughing bouts in patients with whooping cough. We also aimed to find out whether any medicines reduced whooping, vomiting, cyanosis (turning blue because of lack of oxygen), serious complications (such as strokes and seizures), admission to hospital, time spent in hospital or death (from any cause). In addition, we looked at possible side effects of the medicines.

\section{Study characteristics}

The evidence in this review is current up to January 2014. We included 12 studies, which included a total of 578 participants. Ten studies involved a total of 448 children and two involved a total of 130 adolescents and adults. Five studies did laboratory tests to confirm the presence of whooping cough in all participants who took part. Nine studies compared the medicine to a placebo (i.e. a 'dummy' medicine which did not contain the active ingredient being studied) and three studies compared the medicine to no treatment. Seven studies involved hospital inpatients. Three studies reported their start and finish dates; one study recruited participants over 14 months, another over 18 months and another over 31 months.

\section{Key results}

Six studies including 196 participants reported their results in enough detail for us to assess them. Based on these results, antihistamines (one study, 49 participants), pertussis immunoglobulin (one study, 24 participants) and salbutamol (two studies, 42 participants) did not reduce the number of coughing bouts in patients with whooping cough. Neither pertussis immunoglobulin (one study, 46 participants) nor steroids (one study, 11 participants) decreased the length of time participants spent in hospital. One study reported similar rates of side effects in participants treated with pertussis immunoglobulin (4\%; rash) or placebo (5\%; loose stools, pain and swelling of the skin around where the injection was given). Studies of antihistamines, salbutamol and steroids did not report any results on side effects. None of these six studies reported any results on vomiting, cyanosis, serious complications, death or admission to hospital.

\section{Quality of the evidence}

Overall, the quality of evidence was low and many of the studies were conducted some years ago. Only three trials reported adequate details of how the type of treatment given was properly concealed from both participants and healthcare professionals. Methods of recording numbers of coughing bouts and whoops also differed between studies. Estimates of the effects of the different treatments were imprecise due to the small numbers of participants from whom results were available. Additionally, these results may not be generalisable to adults or community settings, since most studies involved children and were done in hospital inpatient settings. 


\section{B A C K G R O U N D}

\section{Description of the condition}

Whooping cough, or pertussis, is a highly infectious disease caused by the gram-negative coccobacillus Bordetella pertussis (B. pertussis). About 16 million cases of pertussis are estimated to occur worldwide each year, of which $95 \%$ are in low-income countries (WHO 2010). Although pertussis vaccination coverage is high, the incidence of pertussis notifications in recent years has been increasing (Campbell 2012). During 2012, pertussis outbreaks were reported in the UK (Public Health England 2013) and in the United States (CDC 2012).The rate of case-fatality among infants in low-income countries may be as high as 4\% (Tan 2005; WHO 2011). There is evidence of a global resurgence in the incidence of pertussis and, with improved recognition, increasing reports of pertussis in adolescent and adult populations (CDC 2005; Cherry 2006; Dworkin 2005; Quinn 2007; Tan 2005). This means neonates and infants are particularly vulnerable to the possibility of disease transmitted by infectious adults in the community. Childhood immunisation has dramatically reduced the incidence of severe disease but the protection provided by childhood immunisation or natural infection is not lifelong. Protection following vaccination is estimated to last between four and 12 years (Wendelboe 2005).

Clinically, pertussis is a prolonged disease and can be classically divided into catarrhal, paroxysmal and convalescent stages. The symptoms during the catarrhal stage are similar to a minor upper respiratory infection or head cold (coryza) with an intermittent non-productive cough commonly lasting one to two weeks, with possible fever. The paroxysmal phase is when coughing begins to occur in spells (paroxysms) that may last for over a minute. The gasping for air between coughing defines the characteristic inspiratory whoop, although infants may not whoop as older children do. Coughing paroxysms can also lead to post-tussive vomiting, which may result in dehydration, especially in lowincome countries (Long 2000).

Serious complications of the disease may occur in young infants, including apnoea, cyanosis, pneumonia, convulsions, cerebral haemorrhage, encephalopathy and death (Mattoo 2005; McEniery 2004; von König 2002). In such cases hospitalisation for supportive care or intensive care may be required. The severity of the paroxysmal phase usually peaks after one or more weeks and may persist for two or three months with an average of five coughing episodes a day before gradual improvement (Harnden 2006). Even without severe complications the coughing spasms are very distressing for the child and parents.

The clinical manifestations of the disease are affected by several known factors, including the age of the patient, immunisation status or history of natural infection, presence of passively acquired antibody, and antibiotic treatment. While the disease stages are foreshortened in immunised children, pertussis can be a major cause of persistent cough. A study in the UK found that $37 \%$ of school children who were coughing for more than two weeks had evidence of a recent infection (Harnden 2006).

In adults the clinical presentation can range from no cough to mild or 'classic pertussis', which includes the characteristic whoop, possible post-tussive vomiting or a prolonged cough illness (Hewlett 2005; Wright 1995). Other complications reported in adults include urinary incontinence (Postels-Multani 1995), hearing loss, inguinal hernia, cracked ribs, carotid artery dissection, pneumonia and pneumothorax, which may result in development of subcutaneous emphysema (Rothstein 2005). These complications can have social and economic implications resulting in the individual being absent from work or school and requiring frequent use of healthcare resources (Rothstein 2005).

Diagnosis of infection in the older population is important for treatment and surveillance purposes, but also to prevent transmission to unvaccinated babies. Recent advances in laboratory diagnostic methods have rapidly evolved from the less sensitive techniques such as culture and antigen detection to polymerase chain reaction (PCR), and the more sensitive antibody detection in serum and oral fluid against pertussis toxin (PT) (Fry 2013). These advances have contributed to rapid and reliable identification which help with treatment and control measures.

The current global increase of pertussis and growing awareness of the implications in older populations have led to new strategies in improving vaccine coverage. Many countries, like the UK, have changed from the whole cell vaccine to the acellular vaccine. Vaccine regimes have also been extended in some countries to include pre-school and adolescent boosters as well as incorporating the 'cocoon strategy' that aims to ensure vaccine coverage of adolescents, adults and postpartum women (Forsyth 2005; Ward 2005); a strategy currently implemented in Australia and parts of the USA. Overall, much effort has been placed on standardising case definitions of surveillance and outbreak investigations. Diagnostic methods are advancing and considerable progress has been made in improving the understanding of pertussis even at the molecular level (King 2008). There are difficulties for those in low-income countries where these tools may not be available. The current challenge is assisting those that suffer from the consequences of this disease.

\section{Description of the intervention}

Treatment options depend on the stage of disease. In the early stages options are fairly standard and the preferred agents include a short treatment of macrolide antibiotics such as azithromycin or erythromycin (Altunaiji 2011). Antibiotics have no effect on the clinical symptoms or course of pertussis but are prescribed primarily to eradicate $B$. pertussis from the nasopharynx and to limit the spread of infection (Altunaiji 2011).

Much of the morbidity of whooping cough is due to the effects of the paroxysmal cough. The treatment of the cough is symptomatic, that is, treatment aims to reduce the severity of the cough paroxysms until the disease has run its course (Long 2000), but the value of current interventions used to relieve the ongoing symptoms is limited. The treatments that have been recommended include corticosteroids (for example, dexamethasone), salbutamol (beta2adrenergic agonist), pertussis immunoglobulin and antihistamines (for example, diphenhydramine). Experimental data also suggest that leukotriene receptor antagonists (LTRAs) may have some benefit in the treatment of pertussis-induced cough (Thivierge 2001; Vandebriel 2007).

\section{How the intervention might work}

Corticosteroids, such as dexamethasone, are synthetic adrenocortical steroids. These drugs alter the body's natural defensive response, reduce symptoms such as swelling and 
allergic-type reactions, and are often used to treat different kinds of inflammation. Salbutamol is a beta2-adrenergic agonist widely used for the relief of bronchospasm in conditions such as asthma and chronic obstructive pulmonary disease. There are a number of different types of antihistamine medicines available that are classified as either first generation or second generation, the difference being that the latter causes less drowsiness. Antihistamines work by blocking the effects of histamine, a mediator of airway inflammation, which can lead to symptoms such as sneezing and coughing. Pertussis immunoglobulin products are therapies directed at pertussis toxin, the major virulence factor of $B$. pertussis. LTRAs are cysteinyl leukotriene type 1 receptor antagonists, which are currently used in the treatment of asthma and allergic rhinitis. LTRAs work by inhibiting leukotrienemediated bronchoconstriction and airway inflammation in these patients. In the mouse model, pertussis infection is associated with increased production of the cytokine interleukin-13 (Vandebriel 2007). Interleukin-13 is known to upregulate cysteinyl leukotriene production and receptor expression (Thivierge 2001).

\section{Why it is important to do this review}

Specific treatments for the underlying cause of cough should ideally reduce or eliminate it. Unfortunately, in the case of pertussis, there are no disease-specific therapies available that can relieve the progressive nature of the cough. Although early antibiotic intervention is recommended in suspected or confirmed pertussis cases, this is primarily intended to reduce disease transmission, and has not been shown to alter the clinical course of the disease (Altunaiji 2011). The paroxysmal stage of pertussis can be life-threatening for young infants and distressing for both child and parent. In adults this coughing phase can continue for several weeks, and can be uncomfortable and distressing.

To date there has been no significant evidence of benefit for any individual treatment in reducing the symptoms and morbidity associated with whooping cough.

\section{O B J E C T IVES}

To assess the effectiveness and safety of interventions to reduce the severity of paroxysmal cough in whooping cough in children and adults.

\section{MET HOD S}

\section{Criteria for considering studies for this review}

\section{Types of studies}

Randomised controlled trials (RCTs) and quasi-RCTs comparing the effects of interventions to reduce the severity of coughing paroxysms in whooping cough.

\section{Types of participants}

We included trials of children and adults with whooping cough (as diagnosed by the trial authors) in any setting.

\section{Types of interventions}

We included any intervention (excluding vaccines and antibiotics) aimed at reducing the severity of the coughing paroxysms in whooping cough compared to another treatment for cough (if treatment has also been compared to placebo or no treatment in the same or another trial), placebo or no treatment.

\section{Types of outcome measures}

\section{Primary outcomes}

1. Frequency of paroxysms of coughing.

\section{Secondary outcomes}

1. Frequency of vomiting.

2. Frequency of whoop.

3. Frequency of cyanosis (turning blue) during cough.

4. Development of a serious complication, for example cerebral haemorrhage or convulsions; or presence of subcutaneous emphysema or pneumothorax.

5. Mortality from any cause.

6. Side effects of medication (as defined by authors of identified trials).

7. Admission to hospital.

8. Duration of hospital stay.

\section{Search methods for identification of studies}

\section{Electronic searches}

We updated our searches of the Cochrane Central Register of Controlled Trials (CENTRAL 2014, Issue 1) (accessed 30 January 2014), which contains the Cochrane Acute Respiratory Infections Group's Specialised Register, the Database of Abstracts of Reviews of Effects (DARE) (2014, Issue 2) (accessed 21 February 2014 from The Cochrane Library), MEDLINE (OvidSP) (1950 to 30 January 2014), EMBASE (OvidSP) (1980 to 30 January 2014), AMED (OvidSP) (1985 to 30 January 2014), CINAHL (EbscoHOST) (1980 to 30 January 2014) and LILACS via http://lilacs.bvsalud.org/en/ (30 January 2014). We searched for studies published in languages other than English and ongoing trials in Current Controlled Trials (http://controlled-trials.com/, accessed 21 February 2014).

We developed a search strategy for use in MEDLINE and revised it accordingly for other databases. We combined the search strategy with the Cochrane Highly Sensitive Search Strategy for identifying randomised trials in MEDLINE: sensitivity-maximising version (2008 revision) (Lefebvre 2011). Randomised controlled trial (RCT) filters applied to EMBASE were according to Ovid Clinical Queries: treatment (two or more terms high sensitivity) (Wong 2006a); RCT filters applied to CINAHL were according to EbscoHOST Clinical Queries: Therapy - High Sensitivity (Wong 2006b); and RCT filters applied to LILACS were according to Manríquez 2008.

See Appendix 1, Appendix 2, Appendix 3 and Appendix 4 for the EMBASE, CINAHL, AMED and LILACS search strings.

\section{MEDLINE (OvidSP)}
1. Whooping Cough/
2. Bordetella pertussis/
3. (whoop* or pertus $\left.{ }^{\star}\right)$.tw.
4. 1 or 2 or 3
5. exp Vaccines/
6. exp Anti-Bacterial Agents/
7.6 or 5
$8.4 \operatorname{not} 7$ 


\section{Albuterol/}

10. (salbutamol or albuterol or ventmax or ventolin or volmax or airomir or asmasal or salamol or salbulin).tw

11. beta agonist*.tw.

12. Adrenergic beta-Agonists/

13. Bronchodilator Agents/

14. exp "Nebulizers and Vaporizers"/

15. (inhaler ${ }^{\star}$ or nebuliser ${ }^{\star}$ or nebulizer* or bronchodilator ${ }^{\star}$ or vaporiser $^{\star}$ or vaporizer $\left.^{\star}\right)$.tw.

16. exp Adrenal Cortex Hormones/

17. exp Steroids/

18. steroid $^{\star}$ or corticosteroid ${ }^{\star}$ or corticoid ${ }^{\star}$ or glucocorticoid ${ }^{\star}$ or cortison $^{\star}$ or prednisone or prednisolone or hydrocortisone).tw.

19. exp Expectorants/

20. (mucolytic* or carbocisteine or erdosteine or erdotin or mecysteine or methyl cysteine or visclair or mucoactive).tw.

21. (cough adj5 suppress ${ }^{\star}$ ).tw.

22. exp Antitussive Agents/

23. (antitussive or anti tussive or protussive or pro tussive).tw.

24. codeine.tw.

25. (cough adj5 (remed $^{\star}$ or therap* ${ }^{\star}$ or treatment ${ }^{\star}$ or management or medicine* or medication*).tw.

26. (pholocodine or dextromethorphan or linctus).tw.

27. (demulcent ${ }^{\star}$ or ipecacauanha or expectorant ${ }^{\star}$ ).tw.

28. (decongestant ${ }^{\star}$ or ephedrine or oxymetazoline or phenylephrine or pseudoephrine or xylometazoline).tw.

29. (sudafed or galpseud or galenphol or benylin or calpol or tixulix or robitussin or galsud or actifed or vicks).tw.

30. exp Histamine Antagonists/

31. (benadryl or diphenhydramide or promethazine or brompheniramine or chlorphenamine or doxylamine or triprolidine or chlorphenizamine or phenergan or piriton or anti histamine ${ }^{\star}$ or antihistamin* or histamine antagonist*).tw.

32. Honey/

33. exp Glycerol/

34. Zinc/

35. (honey or glycerol or zinc or glycerin).tw.

36. exp "Hypnotics and Sedatives"/

37. (sedat ${ }^{\star}$ or diazepam or phenobarbitone or phenobarbitol or chlorpromazine or largactil).tw.

38. exp Cholinergic Antagonists/

39. (anticholinergic adj (drug or agent* or therap*)).tw.

40. cholinergic antagonist ${ }^{\star}$. tw.

41. levodropropizine.tw.

42. ipratropium bromide.tw.

43. moguisteine.tw.

44. or/9-43

45.4 and 44

46. randomized controlled trial.pt.

47. controlled clinical trial.pt.

48. randomized.ab.

49. placebo.ab.

50. drug therapy.fs.

51. randomly.ab.

52. trial.ab.

53. groups.ab.

54.46 or 47 or 48 or 49 or 50 or 51 or 52 or 53

55. (animals not (humans and animals)).sh.

56.54 not 55

57.8 and 56

58.56 and 45

59.57 or 58

\section{Searching other resources}

We reviewed reference lists of eligible trials and previous systematic reviews generated by the searches outlined. We attempted to identify all relevant trials irrespective of language and publication status. We assessed non-English language papers through selective translation by a native speaker where possible and conducted translations of full texts where it was deemed necessary. We scanned reference lists of identified articles, conference abstracts, grey literature and pharmaceutical companies for additional published and unpublished trials.

\section{Data collection and analysis}

\section{Selection of studies}

Two review authors (SB and MT or KW) independently screened the results of the literature search and selected eligible trials according to our preset criteria.

\section{Data extraction and management}

One review author (SB or KW) entered data into RevMan 2014. A second review author (SB or KW) checked the entered data. We extracted the following data from each trial: participants (age and gender), criteria used to diagnose whooping cough and type of intervention and outcomes, including side effects.

\section{Assessment of risk of bias in included studies}

Two review authors (SB and MT or KW) independently extracted methodological information from selected papers for the assessment of internal validity. We assessed the quality of trials according to random sequence generation (selection bias), allocation concealment (selection bias), blinding (performance bias and detection bias), incomplete outcome data (attrition bias), selective reporting (reporting bias) and other bias. These were reported individually and not as a score. We contacted trial authors for additional information on data that were unclear or not reported. We resolved review author differences by discussion.

\section{Measures of treatment effect}

We obtained means and standard deviations using standard methods for accumulated data where possible. We expressed the effects as mean differences (MD) with 95\% confidence intervals (Cls).

\section{Unit of analysis issues}

We analysed the single small, cross-over trial as if it was a parallelgroup trial (Krantz 1985).

\section{Dealing with missing data}

We attempted to contact the trial authors for additional information if data from the trial reports were unclear or missing.

\section{Assessment of heterogeneity}

We conducted a test of heterogeneity for each outcome. We examined heterogeneity amongst studies with the $\mathrm{Chi}^{2}$ test (significance was set at $P$ value $<0.05$ ) and 12 statistic (Higgins 2003). We considered other sources of heterogeneity, apart from differences in interventions, namely clinical diversity (children/ adults and different dosages) and study quality. 


\section{Assessment of reporting biases}

We assessed reporting biases using funnel plots where we had sufficient trials and considered reasons for asymmetry if it was noted.

\section{Data synthesis}

Where no heterogeneity was detected, we performed a fixed-effect meta-analysis. Where substantial heterogeneity ( 12 statistic above $50 \%$ ) was detected, we considered possible explanations for this and considered not combining results. Where necessary, we used sensitivity analysis to investigate the contribution of individual trials to any heterogeneity.

\section{Subgroup analysis and investigation of heterogeneity}

We planned subgroup analyses for the following factors.

1. Dosage, if different doses of the same drug were studied, to compare effectiveness of different doses of the same drug.

2. Age (under 12 months, 12 months to five years and over five years), as the severity of clinical features changes with age, thus participants' reactions to treatment may vary.

3. Whooping cough diagnosed bacteriologically or clinically, to compare the effectiveness of treatment in participants with proven and suspected whooping cough.

4. Severity of cough (treated in hospital (more severe) versus ambulatory care (less severe)), to compare how participants with different disease severities respond to treatment.

\section{Sensitivity analysis}

We planned a sensitivity analysis excluding poorer quality trials (unknown/inadequate allocation concealment or quasi-random allocation), if a sufficient number of trials of the same treatment was identified.

\section{RES ULT S}

\section{Description of studies}

See the Characteristics of included studies and Characteristics of excluded studies tables.

\section{Results of the search}

Our 2014 search update retrieved a total of 259 records (116 from MEDLINE, 105 from EMBASE, 21 from LILACS, 1 from AMED and 16 from CINAHL). After excluding duplicates, there were 253 articles. Combining these results with those from our 2012 update, our electronic literature searches retrieved a total of 1620 articles (excluding duplicates), i.e. 744 from MEDLINE, 275 from CENTRAL, 727 from EMBASE, 24 from LILACS, 61 from AMED and 108 from CINAHL. We identified 28 potentially eligible trials after screening the abstracts and titles. We identified an additional three eligible trials after scanning the reference lists of full-text papers. Twelve trials were eligible for inclusion.

\section{Included studies}

We included 12 trials on the basis of published data only (Danzon 1988; Ghaffari 2011; Granstrom 1991; Halperin 2007; Krantz 1985; Lucchesi 1949; Mertsola 1986; Miraglia 1984; Pavesio 1977; Roberts 1992; Wang 2014; Zoumboulakis 1973).

In four trials, whooping cough was diagnosed bacteriologically, six clinically, and two both bacteriologically and clinically. Reports were generally old, with the earliest study being published in 1949, three in the 1970s, four in the 1980s and two in the 1990s, with the most recent published in 2014. Studies were mostly performed in high-income countries, including Greece, Finland, New Zealand and the UK. Two trials each were from Canada, Italy and Sweden and one trial was conducted in Iran.

Interventions in the trials included antihistamines, pertussis immunoglobulin, corticosteroids, salbutamol, tramadol and montelukast. Data from only six trials were extractable and suitable for analysis in relation to our pre-specified outcomes. Several trial authors were contacted for additional information by the previous review authors (Pillay 2003), with one response received. We contacted one further trial author for more information and the data required were promptly provided.

\section{Excluded studies}

We reviewed the full-text versions of 15 studies, which were not included in this review. In six studies treatment was not randomly allocated (Ames 1953; Balagtas 1971; Bertaggia 1972; Eichlseder 1963; Pavesio 1979; Torre 1993). In five studies, the method used to allocate treatment was unclear (Brunskill 1986; Chandra 1972; Giuliani 1966; Musso 1982; Sacchetti 1982). One study did not include a comparator group for the intervention studied (Bruss 1999). In three studies details of the treatment given to the comparator group were unclear (Badr-El-Din 1976; Leen 1989; Lewis 1984). Details of these excluded studies are presented in the Characteristics of excluded studies table.

\section{Risk of bias in included studies}

Often trial methods would use the word 'random' and 'doubleblinded' but did not describe the generation of the random sequence or who was blinded. Of the 12 included trials, two were quasi-RCTs, nine were RCTs (five with method of randomisation not stated) and one was a cross-over trial. Allocation concealment was clearly adequate in three trials (Danzon 1988; Halperin 2007; Wang 2014), not stated in four (Ghaffari 2011; Lucchesi 1949; Pavesio 1977; Zoumboulakis 1973), and unclear in five (Granstrom 1991; Krantz 1985; Mertsola 1986; Miraglia 1984; Roberts 1992). Three trials were double-blinded (Danzon 1988; Halperin 2007; Wang 2014); blinding methods in the remaining trials were inadequately described. Five trials included all participants in the final analysis; three had greater than $90 \%$ of the participants, one had $53 \%$ of the participants, and in three, loss to follow-up was unclear. Intention-to-treat (ITT) analysis was reported in three of the 12 trials (Ghaffari 2011; Halperin 2007; Wang 2014). The quality of reporting of methods was poor in most trials.

The overall risk of bias is presented graphically in Figure 1 and summarised in Figure 2. 
Figure 1. 'Risk of bias' graph: review authors' judgements about each risk of bias item presented as percentages across all included studies.

Random sequence generation (selection bias)

Allocation concealment (selection bias)

Blinding (performance bias and detection bias)

Incomplete outcome data (attrition bias)

Selective reporting (reporting bias)

Other bias
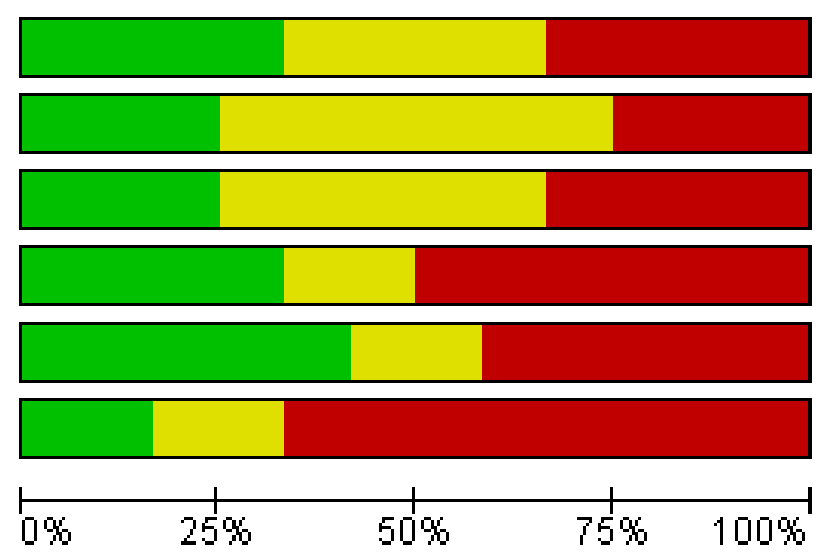
Figure 2. 'Risk of bias' summary: review authors' judgements about each risk of bias item for each included study.

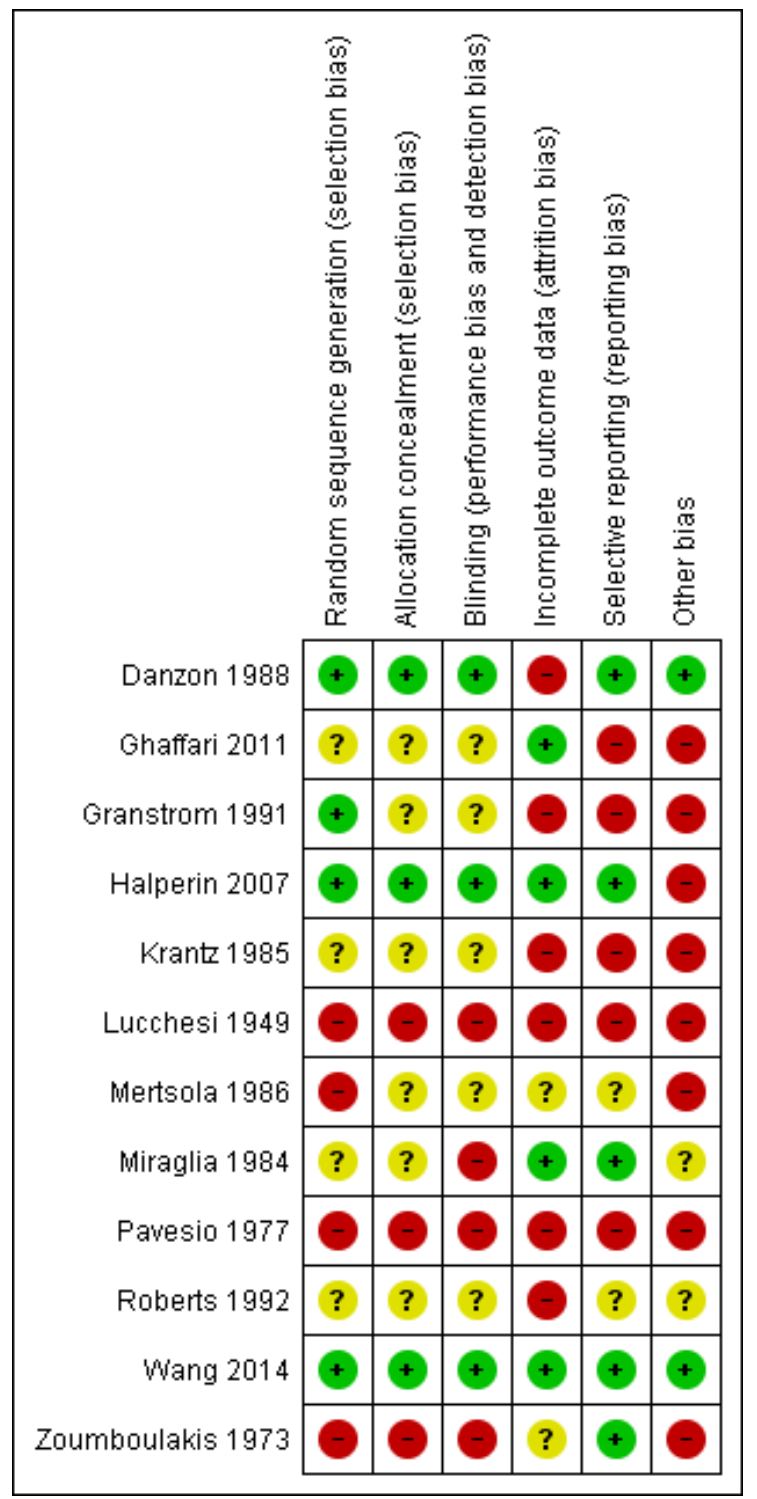

\section{Allocation}

In three trials the treatment assignment was adequately concealed prior to allocation (Danzon 1988; Halperin 2007; Wang 2014), but was unclear or not available in the remaining nine trials.

\section{Blinding}

We deemed three trials to be double-blinded trials (Danzon 1988; Halperin 2007; Wang 2014). The majority were stated to be blinded but insufficient details were given to suggest whether the participants, outcome assessors or personnel were blinded. Three trials were not found to be blinded (Lucchesi 1949; Pavesio 1977; Zoumboulakis 1973).

\section{Incomplete outcome data}

Four trials included data for all study participants in their results (Ghaffari 2011; Halperin 2007; Miraglia 1984; Wang 2014). For the remaining trials either there was not enough information available to determine adequate outcome data or there was a difference in the proportion of incomplete outcome data across groups.

\section{Selective reporting}

The majority of trials had inadequate details in their protocol, or data were not reported in a way to assess this.

\section{Other potential sources of bias}

The process of assessing and measuring outcomes was variable amongst the trials. The scoring of whoops and coughs was not standard and more often subjective and dependent on different scoring systems. In particular, units of time for measuring numbers of whoops and paroxysms of cough were poorly defined and differed between studies. Halperin 2007 reported the numbers of whoops and paroxysms of cough per hour, whereas Danzon 1988 reported the number of paroxysms of cough in a 24-hour period. Krantz 1985 and Mertsola 1986 reported the number of paroxysms of cough per day, and Granstrom 1991 reported the number of 
whoops per day, but none of these studies defined the duration of time in one day. In contrast, the 24-hour period in Danzon 1988 was specifically defined and measured. The numbers of whoops and paroxysms of cough per 24 hours could not be calculated by scaling up the numbers per hour reported in Halperin 2007, because hourly cough frequencies do not remain constant in patients with pertussis (Wang 2014a).

\section{Effects of interventions}

We extracted data for pre-specified outcomes from 12 trials but sufficient data for further analysis were available in only six of these trials (Danzon 1988; Granstrom 1991; Halperin 2007; Krantz 1985; Mertsola 1986; Pavesio 1977). This section presents results from these six trials plus a descriptive summary of side effects reported in all trials that provided these data. Table 1 summarises results for treatments where data were available for analysis. Table 2 presents the results of the other six trials for which data were not suitable for analysis as summary statistics reported by the trial authors (Ghaffari 2011; Lucchesi 1949; Miraglia 1984; Pavesio 1977; Wang 2014; Zoumboulakis 1973).

\section{Primary outcome}

\section{Frequency of paroxysms of coughing}

\section{Antihistamine versus placebo}

Danzon conducted the only trial for the antihistamine diphenhydramine $(\mathrm{N}=49)$ administered orally $(5 \mathrm{mg} / \mathrm{kg} /$ day) in three doses (Danzon 1988). There was no statistically significant difference between the numbers of paroxysms of cough in 24 hours in the diphenhydramine group (mean 22.6, standard deviation (SD) 13.1) and the placebo group (mean 20.7, SD 10.2; mean difference (MD) $1.90 ; 95 \% \mathrm{Cl}-4.7$ to $8.5 ; \mathrm{P}$ value $=0.66$ ) (Analysis 1.1 ).

\section{Pertussis immunoglobulin versus placebo}

Halperin conducted a multicentre randomised controlled trial (RCT) ( $N=25)$ assessing the effect of intravenous pertussis immunoglobulin (P-IGIV) (Halperin 2007). This preparation was administered as a single intravenous infusion initially at $1.5 \mathrm{ml} / \mathrm{kg} /$ hour, increasing gradually to $6.0 \mathrm{ml} / \mathrm{kg} /$ hour over three hours. The rate was decreased if there were any adverse events encountered. There was no statistically significant difference in paroxysmal cough in the treatment group compared to the placebo group: MD -0.07 coughs per hour $(95 \% \mathrm{Cl}-0.42$ to 0.27 ; $\mathrm{P}$ value $=0.65)$ (Analysis 2.1).

\section{Salbutamol versus placebo}

One study conducted with salbutamol was a cross-over trial ( $N=17)$ (Krantz 1985). The dosage of salbutamol was $0.6 \mathrm{mg} / \mathrm{kg} / \mathrm{day}$ in four divided doses for two days. There was no statistically significant difference in coughing paroxysms, with a mean increase of 0.3 coughs per 24 hours in the salbutamol group ( $95 \% \mathrm{Cl}-5.3$ to 6 ). In the second study $(\mathrm{N}=27)$ treatment was administered orally at $0.1 \mathrm{mg} / \mathrm{kg}$ three times a day for 10 days (Mertsola 1986). There was no statistically significant difference in coughing paroxysms: MD -0.7 coughs per day in the salbutamol group $(95 \% \mathrm{Cl}-6.2$ to 4.7$)$. In both trials, data were reported for each 24-hour period. There was no evidence of heterogeneity in paroxysmal cough per 24 hours $(P$ value $=0.79)$. There was no statistically significant difference in coughing paroxysms: MD -0.22 coughs per 24 hours in groups treated with salbutamol $(95 \% \mathrm{Cl}-4.1$ to $3.7 ; \mathrm{P}$ value $=0.91)$ (Analysis 3.1).

\section{Secondary outcomes}

\section{Frequency of vomiting}

None of the studies for which sufficient data were available for analysis reported data relating to this outcome.

\section{Frequency of whoop}

Pertussis immunoglobulin versus placebo

Granstrom conducted a trial $(\mathrm{N}=67)$ assessing the effect of two forms of immunoglobulins (mono-component toxoid pertussis vaccine and a two-component acellular pertussis vaccine) (Granstrom 1991). Sample groups were divided to receive either pertussis immunoglobulin or placebo and treatment was administered intramuscularly $(8 \mathrm{ml})$. There was no statistically significant difference in the mean number of whoops per day: mean difference (MD) between the treatment and control groups -3.1 per day $(95 \% \mathrm{Cl}-6.2$ to $0.02 ; \mathrm{P}$ value $=0.06)$ (Analysis 2.2). However, this figure could suggest some indication of a potential effect. Halperin 2007 reported no significant differences in whoops per hour in the immunoglobulin group compared to the placebo group: MD -0.06 whoops per hour $(95 \% \mathrm{Cl}-0.34$ to $0.21 ; \mathrm{P}$ value $=0.65)$ (Analysis 2.3).

\section{Frequency of cyanosis (turning blue) during cough}

None of the studies included in this review reported data relating to this outcome.

\section{Development of a serious complication, for example cerebral haemorrhage or convulsions; or presence of subcutaneous emphysema or pneumothorax}

None of the studies included in this review reported data relating to this outcome.

\section{Mortality from any cause}

None of the studies included in this review reported data relating to this outcome.

\section{Side effects of medication (as defined by authors of identified trials)}

\section{Pertussis immunoglobulin}

Granstrom 1991 reported rash in $4.3 \%$ of the treatment group together with loose stools, and pain and swelling at the injection site in 5.3\% of the placebo group. Halperin 2007 reported that P-IGIV was well tolerated by study participants with no infusion-related adverse events. Any adverse events reported were attributed to the disease or intercurrent-related infection.

\section{Steroids}

Zoumboulakis 1973 reported pulmonary infiltrates in $15.1 \%$ of the hydrocortisone group and in $10.7 \%$ of the control group.

\section{Montelukast}

Wang 2014 reported that the proportions of participants with postinfectious cough who reported at least one adverse event were not significantly different between groups (montelukast 21/137, 15.3\%; placebo 31/139, 22.3\%, P value $=0.14$ ). The most common side effects reported were increased mucus production (montelukast, $\mathrm{n}=6$; placebo, $\mathrm{n}=2$ ) and headache (montelukast, $\mathrm{n}$ $=2$; placebo, $n=6$ ). Side effects were not reported in the subgroup 
with laboratory-confirmed pertussis (montelukast, $\mathrm{n}=31$; placebo, $\mathrm{n}=39$ ).

\section{Chlophedianol plus sobrerol}

Miraglia 1984 reported diarrhoea in $6.7 \%$ of the placebo group but stated that the diarrhoea was not related to being a part of the study, as diarrhoea was recorded two days after treatment with placebo.

\section{Tramadol}

Ghaffari 2011 reported drowsiness as a side effect in one patient in the intervention arm. No side effects were reported in the control arm.

\section{Admission to hospital}

None of the studies included in this review reported data relating to this outcome.

\section{Duration of hospital stay}

\section{Pertussis immunoglobulin versus placebo}

Granstrom 1991 reported that there was no statistically significant difference in the duration of hospital stay: MD -0.7 days in the treatment group $(95 \% \mathrm{Cl}-3.8$ to 2.4 ; $\mathrm{P}$ value $=0.66)$ (Analysis 2.4$)$.

\section{Steroids versus placebo}

One study ( $\mathrm{N}=11)$ assessed the effect of dexamethasone on the duration of hospital stay (Roberts 1992). Treatment was administered orally at $0.3 \mathrm{mg} / \mathrm{kg}$ for four days. There was no statistically significant difference in duration of hospital stay, with a MD -3.5 days in the dexamethasone group $(95 \% \mathrm{Cl}-15.3$ to $8.4 ; \mathrm{P}$ value $=0.57$ ) (Analysis 4.1).

\section{DISCUSSION}

\section{Summary of main results}

This systematic review examining the symptomatic treatment of whooping cough has found that there is insufficient evidence to support the use of current interventions. Only one trial indicated some benefit in the use of pertussis immunoglobulin but more research is required to substantiate this finding.

\section{Overall completeness and applicability of evidence}

For the 2009 review we updated the earlier search strategy (Pillay 2003; Appendix 5), by including all treatment terms and interventions associated with whooping cough before excluding terms such as antibiotics and vaccines. Antibiotic and vaccine reviews have been performed for these interventions. A Cochrane Review on antibiotic treatment in whooping cough has been published (Altunaiji 2011), and the previously withdrawn Cochrane Review on acellular vaccines for preventing whooping cough in children, Tinnion 2001, has been updated by a new team of authors (Zhang 2012). In 2009 we added one included trial to the previous review published in 2003 (Pillay 2003). We did not identify any new studies to include when we updated our searches in 2012. We included two new studies following our 2014 search update (Ghaffari 2011; Wang 2014), but neither of these reported data suitable for further analysis in relation to our pre-specified outcomes.
No statistically significant effects were found for any of the interventions. Pertussis immunoglobulin could plausibly result in anything from a decrease in the mean number of whoops by 6.22 over 24 hours to an increase of 0.02 over 24 hours (Granstrom 1991). For all the other interventions sample sizes were small and confidence intervals for the mean differences were wide. This indicates that there is insufficient evidence to reach any conclusion regarding their effectiveness. The pre-specified subgroup and sensitivity analyses were not feasible because of the small number of trials identified.

\section{Quality of the evidence}

Twelve trials from our literature search between 1950 and 2014 met our inclusion criteria. Most of the trials were generally old and poorly reported while the majority of randomised controlled trials (RCTs) were performed in the 1980s. This partially explains the poor quality and inconclusive nature of the trials. There were two exceptions (Halperin 2007; Wang 2014), which were well designed and well executed.

\section{Potential biases in the review process}

There were several key limitations to the included trials. The trials were too heterogenous in regards to their interventions and outcomes to allow pooling of results. The trials varied greatly in dose regimes and duration of treatment. There was inconsistency in measuring outcomes and the timing of those intervals. The outcome data were also presented differently, that is, frequency of whoops per hour or duration of symptoms. Methods of monitoring coughs were variable but expected to be due to the year of publication. The later trials were likely to include the recording of the progressive cough with monitors and digital equipment. Age and sex of children/participants enrolled in the trials were not always mentioned and only one study from which data were suitable for analysis included children over 12 years of age and adults (Mertsola 1986). Immunisation status and antibiotic treatments were not always stated. In the majority of trials participants were given antibiotics prior to intervention.

Fifteen trials were excluded from this review. These trials might have provided some useful information but the many methodological errors, including poor-quality methods or analysis, problems with recruitment, time frame and allocation of patients and non-interpretable results, lead to several forms of bias and misleading conclusions. In some of the excluded trials the trial authors concluded that their work was more of a pilot study and more research on their intervention was recommended.

\section{Agreements and disagreements with other studies or reviews}

Throughout much of the literature we report a lack of controlled trials and contradictory reports for cough relief in whooping cough. No strong evidence exists of any treatment that can relieve the serious cough caused by whooping cough, although there was one study that found some evidence that pertussis immunoglobulin preparations might help. There are many short, single-blinded trials, clinical observations and 'personal impressions' that discuss promising results for patients and may indeed hold some credit. However, well-designed, placebo-controlled, double-blind trials of potential agents and or combinations are lacking and such trials need to be initiated for those with pertussis in a similar way that trials of therapies for croup and asthma have been performed. This 
void in new therapies for cough is not limited to those suffering from pertussis but is a general problem for treating coughs of various causes. Chung 2009 has noted that new therapies for cough are lacking while in several countries there are growing concerns about the safety and efficacy of commonly used cough medicines (MHRA 2009). Overall there is a need for new, effective antitussive drugs for patients with whooping cough.

\section{AUTHORS' CONCLUSIONS \\ Implications for practice}

Given the uncertain effectiveness and potential side effects of interventions for the cough in whooping cough, there appears to be no justification for their use.

\section{Implications for research}

Given the growing prevalence of pertussis in infants, adolescents and adults, there is an urgent need for large, well-designed randomised controlled trials (RCTs) to identify effective antitussive treatments for pertussis-induced cough. More importantly, goodquality, well-reported RCTs with adequate statistical power are required. Well-designed trials are required and the design should follow CONSORT (Consolidated Standards of Reporting Trials) guidelines (www.consort-statement.org). CONSORT comprises a checklist and flow diagram to help improve the quality of reports of RCTs. The checklist includes descriptions of the randomisation procedure (allocation concealment), the mechanisms of blinding, number of people lost during the follow-up and some details about the analysis made.

\section{ACKNOWLEDGEMENTS}

We wish to acknowledge the previous authors of this Cochrane Review, Dr Pillay and Dr Swingler.

We wish to thank the staff at the Nuffield Department of Primary Care Health Sciences, Oxford, UK. We wish to thank trial author Dr Scott Halperin for providing additional data for analysis. We would like to thank Dr Annette Pluddemann, Research Assistant, Oxford Centre for Monitoring and Diagnosis (MaDOx), and Mrs Mina Davoudianfar, Nuffield Department of Primary Care Health Sciences, Oxford, for translating non-English language articles. Finally, we wish to thank Tracey Lloyd, James Cherry, Max Bulsara and Chris Del Mar, who commented on the 2009 updated draft review, and Soumyadeep Bhaumik, Bhupendrasinh Chauhan, Janet Wale, Conor Teljeur and Chris Del Mar, who commented on the 2014 updated draft review. 


\section{R E F E R E N C E S}

\section{References to studies included in this review}

\section{Danzon 1988 \{published data only\}}

Danzon A, Lacroix J, Infante-Rivard C, Chicoine L. A double blind clinical trial on diphenhydramine. Acta Paediatrica Scandinavica 1988;77(4):614-5.

\section{Ghaffari 2011 \{published data only\}}

Ghaffari J, Saffar M, Salehifar E, Ghasemian R, Khademloo M. Anti-cough effects of tramadol in patients with pertussis. Journal of Mazandaran University of Medical Sciences 2011;21(84):106-11.

\section{Granstrom 1991 \{published data only\}}

Granstrom M, Olinder-Nielsen AM, Holmbard P, Mark A, Hanngren K. Specific immunoglobulin for treatment of whooping cough. Lancet 1991;338(8777):1230-3.

\section{Halperin 2007 \{published data only\}}

Halperin SA, Vaudry W, Boucher FD, Mackintosh K, Waggener TB, Smith B. Is pertussis immunoglobulin efficacious for the treatment of hospitalized infants with pertussis? No answer yet. Pediatric Infectious Disease Journal 2007;26(1):79-81.

\section{Krantz 1985 \{published data only\}}

Krantz I, Norrby SR, Trollfors B. Salbutamol vs placebo for treatment of pertussis. Pediatric Infectious Diseases Journal 1985;4(6):638-40.

\section{Lucchesi 1949 \{published data only\}}

Lucchesi PF, La Boccetta AC. Whooping cough treated with pertussis immune serum (human). American Journal of Diseases of Children 1949;77(1):15-24.

\section{Mertsola 1986 \{published data only\}}

Mertsola J, Viljanen MK, Ruuskanen O. Salbutamol in the treatment of whooping cough. Scandinavian Journal of Infectious Disease 1986;18(6):593-4.

\section{Miraglia 1984 \{published data only\}}

Miraglia del Giudice, Capristo AF, Mirra G, Maiello N, Coppola T. A controlled double blind study in the efficacy of chlophedianol - sobrerol in the treatment of infantile whooping cough [Studio controllato in doppio cieco sull 'efficacia del clofedanolo sobrerolo nella terapia della pertose del bambino]. Minerva Pediatrica 1984;36(6):1199-206.

\section{Pavesio 1977 \{published data only\}}

Pavesio D, Ponzone A. Salbutamol and pertussis. Lancet 1977;1(8003):150-1.

\section{Roberts 1992 \{published data only\}}

Roberts I, Gavin R, Lennon D. Randomized controlled trial of steroids in treatment of pertussis [letter]. Archives of Disease in Childhood 1992;11(11):982-3.
Wang 2014 \{published data only\}

Wang K, Birring SS, Taylor K, Fry NK, Hay AD, Moore, et al. Montelukast for postinfectious cough in adults: a double-blind randomised placebo-controlled trial. Lancet 2014;2(1):35-43.

\section{Zoumboulakis 1973 \{published data only\}}

Zoumboulakis D, Anagnostakis D, Albanis V, Matsaniotis N. Steroids in treatment of pertussis: a controlled clinical trial. Archives of Disease in Childhood 1973;48(1):51-4.

\section{References to studies excluded from this review}

Ames 1953 \{published data only\}

Ames RG, Cohen SM, Fischer AE, Kohn J, McPherson AZ, Marlow J, et al. Comparison of the therapeutic efficacy of four agents in pertussis. Pediatrics 1953;11(4):323-37.

Badr-El-Din 1976 \{published data only\}

Badr-el-din MK, Aref GH, Kassem AS, Abdel-Moneim MA, Abbassy $A$. A beta-adrenergic stimulant, salbutamol, in the treatment of pertussis. Journal of Tropical Medicine and Hygiene 1976;79(10):218-9.

\section{Balagtas 1971 \{published data only\}}

Balagtas RC, Nelson KE, Levin S, Gotoff SP. Treatment of pertussis with pertussis immunoglobulin. Journal of Pediatrics 1971;79(2):203-8

\section{Bertaggia 1972 \{published data only\}}

Bertaggia A, Cavinato G. Use of hyperimmune human globulins in whooping cough [Sull'impiego delle globuline umane iperimmuni nella pertosse]. Minerva Pediatrica 1972;24(20):847-53.

Brunskill 1986 \{published data only\} Brunskill A, Langdon D. Salbutamol and pertussis [letter]. Lancet 1986;2(8501):282-3.

\section{Bruss 1999 \{published data only\}}

Bruss JB, Malley R, Halperin S, Dobson S, Dhalla M, Mciver J, et al. Treatment of severe pertussis: a study of the safety and pharmacology of intravenous pertussis immunoglobulin. Pediatric Infectious Disease Journal 1999;18(6):505-11.

\section{Chandra 1972 \{published data only\}}

Chandra H, Karan S, Mathur YC. Evaluation of betamethasone and isoniazid along with chloramphenicol in the management of whooping cough. Indian Pediatrics 1972;9(2):70-4.

Eichlseder 1963 \{published data only\}

Eichlseder W. Test of the efficacy of pertussis-hyperimmune globulin and chloramphenicol against whooping cough in a double blind trial [Uberprufung der Wirksamkeit von Pertussis-Hyper-immun-Globulin and Chloramphenicol auf den Keuchhusten im doppelten Blindversuch]. Aus den Kinderkrankenhaus Munchen-Schwabing 1963;169:6-31. 
Giuliani 1966 \{published data only\}

Giuliani G, Rapellini M. Apropos of hyperimmune globulins in the treatment of whooping-cough [A proposito elle globuline iperimmuni net trattamento della pertose]. Minerva Medica 1966;57(101):4372-5.

\section{Leen 1989 \{published data only\}}

Leen CL, Jaulim A, Wilkins E, Mandal BK. Sodium cromoglycate in the treatment of pertussis. Journal of Infection 1989;19(1):82.

\section{Lewis 1984 \{published data only\}}

Lewis D. Double blind controlled trial in the treatment of whooping cough using drosera. Midlands Homoeopathy Research Group Newsletter 1984;11:49-58.

\section{Musso 1982 \{published data only\}}

Musso A, Giacchino M, Vaccino P, Sacchetti C, Patrito A, Vietti M, et al. Modern concepts of drug therapy of whooping cough [Moderni concetti sulla terapia farmacologica della pertosse]. Minerva Pediatrica 1982;34(3):125-30.

\section{Pavesio 1979 \{published data only\}}

Pavesio D, Mora P, Levi P. Preliminary results with salbutamol in the treatment of pertussis. Minerva Pediatrica 1979;31(11):901-5

\section{Sacchetti 1982 \{published data only\}}

Sacchetti C, Musso A, Vaccin P, Nigro N, Motta L. Evaluation of treatment of pertussis with specific gamma globulins in the first 6 months of life (based on complications of pertussis) [Valutazione della terapia antipertossica con gammaglobuline specifiche nei primi sei mesi di vita (in base alle complicanze)]. Minerva Pediatrica 1982;34(1-2):66-7.

\section{Torre 1993 \{published data only\}}

Torre D, Tambini R, Ferrario G, Bonetta G. Treatment with steroids in children with pertussis. Pediatric Infectious Disease Journal 1993;12(5):419-20.

\section{Additional references}

\section{Altunaiji 2011}

Altunaiji S, Kukuruzovic R, Curtis N, Massie J. Antibiotics for whooping cough (pertussis). Cochrane Database of Systematic Reviews 2011, Issue 7. [DOI: 10.1002/14651858.CD004404.pub3]

\section{Campbell 2012}

Campbell H, Amirthalingam G, Andrews N, Fry NK, George RC, Harrison TG, et al. Accelerating control of pertussis in England and Wales. Emerging Infectious Diseases 2012;18:38-47.

\section{CDC 2005}

Centres for Disease Control and Prevention. Pertussis - United States, 2001-2003. Morbidity and Mortality Weekly Report (MMWR) 2005;54(50):1283-6.

\section{CDC 2012}

Centers for Disease Control and Prevention. Pertussis epidemic - Washington, 2012. Morbidity and Mortality Weekly Report (MMWR) 2012;61(28):517-22.

\section{Cherry 2006}

Cherry JD. Epidemiology of pertussis. Pediatric Infectious Disease Journal 2006;25(4):361-2.

\section{Chung 2009}

Chung KF. Clinical cough Vl: the need for new therapies for cough: disease-specific and symptom-related antitussives. Handbook of Experimental Pharmacology 2009;187:343-68.

\section{Dworkin 2005}

Dworkin MS. Adults are whooping, but are internists listening? Annals of Internal Medicine 2005;142(10):832-5.

\section{Forsyth 2005}

Forsyth K, Tan T, von Konig CH, Caro JJ, Plotkin S. Potential strategies to reduce the burden of pertussis. Pediatric Infectious Disease Journal 2005;24(Suppl 5):83-6.

\section{Fry 2013}

Fry NK, Litt DJ, Duncan J, Vaghji L, Warrener L, Samuel D, et al. Modelling anti-pertussis toxin IgG antibody decay following primary and preschool vaccination with an acellular pertussis vaccine in UK subjects using a modified oral fluid assay. Journal of Medical Microbiology 2013;62:1281-9.

\section{Harnden 2006}

Harnden A, Grant C, Harrison T, Perera R, Brueggemann AB, Mayon-White R, et al. Whooping cough in school age children with persistent cough: prospective cohort study in primary care. BMJ 2006;333(7560):174-7.

\section{Hewlett 2005}

Hewlett EL, Edwards KM. Clinical practice: pertussis - not just for kids. New England Journal of Medicine 2005;352:1215-22.

\section{King 2008}

King AJ, van Gorkom T, Pennings JL, van der Heide HG, He Q, Diavatopoulos D, et al. Comparative genomic profiling of Dutch clinical Bordetella pertussis isolates using DNA microarrays: identification of genes absent from epidemic strains. $B M C$ Genomics 2008;9:311.

\section{Lefebvre 2011}

Lefebvre C, Manheimer E, Glanville J. Chapter 6: Searching for studies. In: Higgins JPT, Green S editor(s). Cochrane Handbook for Systematic Reviews of Interventions Version 5.1.0 [updated March 2011]. The Cochrane Collaboration. Available from www.cochrane-handbook.org. Chichester, UK: Wiley-Blackwell, 2011.

\section{Long 2000}

Long SS. Pertussis (Bordetella pertussis and B. parapertussis) Behrman: Nelson Textbook of Pediatrics. 16th Edition. Philadelphia: WB Saunders, 2000:840-1.

\section{Manríquez 2008}

Manríquez JJ. A highly sensitive search strategy for clinical trials in Literatura Latino Americana e do Caribe em Ciências da Saúde (LILACS) was developed. Journal of Clinical Epidemiology 2008;61(4):407-11. 


\section{Mattoo 2005}

Mattoo S, Cherry JD. Molecular pathogenesis, epidemiology, and clinical manifestations of respiratory infections due to Bordetella pertussis and other Bordetella subspecies. Clinical Microbiology Reviews 2005;18(2):326-82.

\section{McEniery 2004}

McEniery JD, Delbridge RG, Reith DM. Infant pertussis deaths and the management of cardiovascular compromise. Journal of Paediatric Child Health 2004;40(4):230-2.

\section{MHRA 2009}

Medicines and Healthcare products Regulatory Agency. Better medicines for children's coughs and cold - Press Release. http:// www.mhra.gov.uk/NewsCentre/Pressreleases/CON038902 (accessed February 2009) 2009.

\section{Postels-Multani 1995}

Postels-Multani S, Schmitt HJ, Wirsing von Konig CH, Bock HL, Bogaerts $\mathrm{H}$. Symptoms and complications of pertussis in adults. Infection 1995;23(3):139-42.

\section{Public Health England 2013}

Public Health England. Pertussis in England and Wales: fourth quarter 2012 data and consolidated annual report for 2012. Health Protection Report Numbers 14-17 2013; Vol. 7.

\section{Quinn 2007}

Quinn HE, Mclntyre PB. Pertussis epidemiology in Australia over the decade 1995-2005 - trends by region and age group. Communicable Disease Intelligence 2007;31(2):205-15.

\section{RevMan 2014 [Computer program]}

The Nordic Cochrane Centre, The Cochrane Collaboration. Review Manager (RevMan). Version 5.3. Copenhagen: The Nordic Cochrane Centre, The Cochrane Collaboration., 2014.

\section{Rothstein 2005}

Rothstein E, Edwards K. Health burden of pertussis in adolescents and adults. Pediatric Infectious Disease Journal 2005;24(5):S44-7.

\section{Tan 2005}

Tan T, Trindade E, Skowronski D. Epidemiology of pertussis. Pediatric Infectious Disease Journal 2005;24(Suppl 5):10-8.

\section{Thivierge 2001}

Thivierge M, Stankova J, Rola-Pleszczynski M. IL-13 and IL-4 up-regulate cysteinyl leukotriene 1 receptor expression in human monocytes and macrophages. Journal of Immunology 2001;167:2855-60.

\section{Tinnion 2001}

Tinnion ON, Hanlon M. Acellular vaccines for preventing whooping cough in children. Cochrane Database of Systematic Reviews 2001, Issue 4. [DOI: 10.1002/14651858.CD001478.pub2]

\section{Vandebriel 2007}

Vandebriel RJ, Gremmer ER, Vermeulen JP, Hellwig SM, Dormans JA, Roholl PJ, et al. Lung pathology and immediate hypersensitivity in a mouse model after vaccination with pertussis vaccines and challenge with Bordetella pertussis. Vaccine 2007;25:2346-60.

\section{von König 2002}

von König CH, Halperin S, Riffelman M, Guiso N. Pertussis of adults and infants. Lancet Infectious Disease 2002;2(12):744-50.

\section{Wang 2014a}

Wang K, Fry NK, Campbell H, Amirthalingam G, Harrison TG, Mant $D$, et al. Whooping cough in school age children presenting with persistent cough in UK primary care after introduction of the preschool pertussis booster vaccination: prospective cohort study. BMJ 2014;348:g3668.

\section{Ward 2005}

Ward A, Caro J, Bassinet L, Housset B, O'Brian JA, Guiso N. Health and economic consequences of an outbreak of pertussis among healthcare workers in a hospital in France. Infection Control and Hospital Epidemiology 2005;26(3):288-92.

\section{Wendelboe 2005}

Wendelboe AM, Van Rie A, Salmaso S, Englund JA. Duration of immunity against pertussis after natural infection or vaccination. Pediatric Infectious Disease Journal 2005;24(5):S58-61.

\section{WHO 2010}

World Health Organization. Pertussis vaccines: WHO position paper. Weekly Epidemiological Record 2010;85(40):385-400.

\section{WHO 2011}

World Health Organization. Immunization, Vaccines and Biologicals. Pertussis. http://www.who.int/immunization/ topics/pertussis/en/ (last updated 21 June 2011) (accessed 18 July 2014).

\section{Wong 2006a}

Wong SS, Wilczynski NL, Haynes RB. Developing optimal search strategies for detecting clinically sound treatment studies in EMBASE. Journal of the Medical Library Association 2006;94(1):41-7.

\section{Wong 2006b}

Wong SS, Wilczynski NL, Haynes RB. Optimal CINAHL search strategies for identifying therapy studies and review articles. Journal of Nursing Scholarship 2006;38(2):194-9.

\section{Wright 1995}

Wright SW, Edwards KM, Decker MD, Zeldin MH. Pertussis infection in adults with persistent cough. JAMA 1995;273(13):1044-6.

\section{Zhang 2012}

Zhang L, Prietsch SOM, Axelsson I, Halperin SA. Acellular vaccines for preventing whooping cough in children. Cochrane Database of Systematic Reviews 2012, Issue 3. [DOI: 10.1002/14651858.CD001478.pub5] 


\section{References to other published versions of this review}

\section{Bettiol 2010}

Bettiol S, Thompson MJ, Roberts NW, Perera R, Heneghan CJ, et al. Symptomatic treatment of the cough in whooping cough. Cochrane Database of Systematic Reviews 2010, Issue 1. [DOI: 10.1002/14651858.CD003257.pub3]

\section{Bettiol 2012}

Bettiol S, Wang K, Thompson MJ, Roberts NW, Perera R, Heneghan CJ, et al. Symptomatic treatment of the cough in

\section{CHARACTERISTICS OF STUDIES}

Characteristics of included studies [ordered by study ID]

\section{Danzon 1988}

\begin{tabular}{ll}
\hline Methods & $\begin{array}{l}\text { Randomly allocated (table of random numbers controlled by the pharmacy) unknown to the investi- } \\
\text { gator. Performed in a double-blinded pattern. Intention-to-treat analysis was not reported. Loss to fol- } \\
\text { low-up was unclear }\end{array}$ \\
\hline Participants & $\begin{array}{l}49 \text { inpatients (gender not specified) under } 1 \text { year of age. Vaccination status and previous antibiotic } \\
\text { treatment was not reported. Bacteriologically diagnosed pertussis }\end{array}$ \\
\hline Interventions & Diphenhydramine $5 \mathrm{mg} / \mathrm{kg} /$ day orally in 3 doses \\
\hline Outcomes & $\begin{array}{l}\text { Average number of paroxysms of cough over } 24 \text { hours (between } 25 \text { th and } 48 \text { th hour after starting treat- } \\
\text { ment) }\end{array}$ \\
\hline Notes & Coughs monitored with microphones
\end{tabular}

\section{Risk of bias}

\begin{tabular}{lll}
\hline Bias & Authors' judgement & Support for judgement \\
\hline $\begin{array}{l}\text { Random sequence genera- } \\
\text { tion (selection bias) }\end{array}$ & Low risk & Table of random numbers \\
\hline $\begin{array}{l}\text { Allocation concealment } \\
\text { (selection bias) }\end{array}$ & Low risk & Control allocation with double-blind pattern \\
\hline $\begin{array}{l}\text { Blinding (performance } \\
\text { bias and detection bias) } \\
\text { All outcomes }\end{array}$ & Low risk & $\begin{array}{l}\text { Appearance, smell and taste of active drug and placebo syrups were similar. } \\
\text { Coughs monitored around the clock with sets of microphones }\end{array}$ \\
\hline $\begin{array}{l}\text { Incomplete outcome data } \\
\text { (attrition bias) } \\
\text { All outcomes }\end{array}$ & High risk & - \\
\hline $\begin{array}{l}\text { Selective reporting (re- } \\
\text { porting bias) }\end{array}$ & Low risk & Report pre-specified study outcome \\
\hline \begin{tabular}{l} 
Other bias \\
\hline
\end{tabular} & Low risk & - \\
\hline
\end{tabular}

whooping cough. Cochrane Database of Systematic Reviews 2012, Issue 5. [DOI: 10.1002/14651858.CD003257.pub4]

\section{Pillay 2003}

Pillay V, Swingler G. Symptomatic treatment of the cough in whooping cough. Cochrane Database of Systematic Reviews 2003, Issue 4. [DOI: 10.1002/14651858.CD003257.pub2] 
Ghaffari 2011

\begin{tabular}{ll}
\hline Methods & Single-blinded randomised controlled trial. Intervention and control groups were matched at baseline \\
in relation to severity of pertussis symptoms and sex profile. No other baseline characteristics were re- \\
ported
\end{tabular}

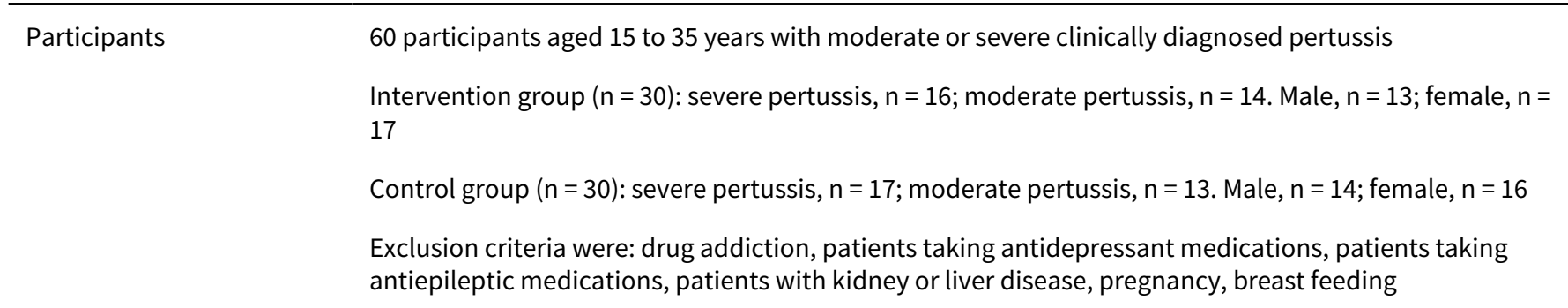

\begin{tabular}{ll}
\hline Interventions & Intervention group: azithromycin $500 \mathrm{mg}$ on day 1 , azithromycin $250 \mathrm{mg}$ daily from days 2 to 5 , ceti- \\
& rizine $10 \mathrm{ml}$ daily from days 1 to 5 , tramadol $50 \mathrm{mg}$ daily from days 1 to 5 \\
& Control group: azithromycin $500 \mathrm{mg}$ on day 1 , azithromycin $250 \mathrm{mg}$ daily from days 2 to 5 , cetirizine 10 \\
& $\mathrm{ml}$ daily from days 1 to 5
\end{tabular}

Outcomes

Moderate or severe pertussis symptoms assessed by questionnaire devised by researchers based on CDC and WHO clinical case definitions of pertussis; quality of life; return to work

\section{Notes}
Pertussis symptoms included: facial cyanosis, facial flushing, proptosis, post-tussive vomiting, post- tussive syncope, post-tussive fatigue, ability to expectorate, paroxysms of cough consisting of 5 or more coughs, 5 or more paroxysms of cough/day, sleep disturbance

Scores were assigned according to absence or presence of the above symptoms (maximum score 43, higher score indicated more severe symptoms). Moderate pertussis was diagnosed in patients with a score of 16 to 30 . Severe pertussis was diagnosed in patients with a score of 31 to 43

\section{Risk of bias}

\begin{tabular}{|c|c|c|}
\hline Bias & Authors' judgement & Support for judgement \\
\hline $\begin{array}{l}\text { Random sequence genera- } \\
\text { tion (selection bias) }\end{array}$ & Unclear risk & Study does not state how the randomisation sequence was generated \\
\hline $\begin{array}{l}\text { Allocation concealment } \\
\text { (selection bias) }\end{array}$ & Unclear risk & $\begin{array}{l}\text { Study does not state how participants were randomly allocated to the inter- } \\
\text { vention or control group }\end{array}$ \\
\hline $\begin{array}{l}\text { Blinding (performance } \\
\text { bias and detection bias) } \\
\text { All outcomes }\end{array}$ & Unclear risk & $\begin{array}{l}\text { Although study design stated as being single-blinded, no details given about } \\
\text { who was blinded or how blinding was achieved }\end{array}$ \\
\hline $\begin{array}{l}\text { Incomplete outcome data } \\
\text { (attrition bias) } \\
\text { All outcomes }\end{array}$ & Low risk & Outcome data were obtained from all study participants \\
\hline $\begin{array}{l}\text { Selective reporting (re- } \\
\text { porting bias) }\end{array}$ & High risk & $\begin{array}{l}\text { Primary outcome not specified. Main outcomes reported were numbers and } \\
\text { percentages of patients in each group with severe and moderate pertussis } \\
\text { (based on pertussis symptom questionnaire score) after treatment. Unclear } \\
\text { whether questionnaire was completed by participants or clinicians, or whether } \\
\text { outcome data were obtained and analysed blinded to treatment allocation. } \\
\text { Methods of measuring quality of life also unclear and this outcome was only } \\
\text { reported in the intervention group }\end{array}$ \\
\hline
\end{tabular}

Other bias High risk

No laboratory confirmation of pertussis infection. No baseline data provided for either group in relation to age, pertussis vaccination status or antibiotic 
Ghaffari 2011 (Continued)

treatment. Pertussis symptom severity questionnaire and scoring system not

validated. No sample size justification provided. Quality of life outcome

Granstrom 1991

Methods Randomisation done by a computer-generated table of random numbers. A double-blinded, place-
bo-controlled trial. Intention-to-treat analysis was not reported. $91.8 \%$ follow-up

\begin{tabular}{ll}
\hline Participants & Both male and female inpatients, age range 1.1 to 32.3 months. $51 \%$ of the patients had previous an- \\
tibiotic treatment but were not previously vaccinated. Clinical, bacteriological or serological diagnosed \\
pertussis
\end{tabular}

Interventions $\begin{aligned} & \text { Specific immunoglobulin treatment, } 8 \mathrm{ml} \text { intramuscularly injected into the buttocks, } 2 \mathrm{ml} \text { either side on } \\ & \text { the first day of admission and the next dose as soon as possible after the first injection or on the second } \\ & \text { day }\end{aligned}$

\begin{tabular}{ll}
\hline Outcomes & $\begin{array}{l}\text { Duration of paroxysms, vomiting, whoop and hospital stay, mean number of paroxysms. Noted by } \\
\text { nurse and parental reports }\end{array}$ \\
\hline Notes & $\begin{array}{l}\text { None of the children had been immunised. Supportive therapy was provided including erythromycin } \\
\text { and salbutamol }\end{array}$
\end{tabular}

\section{Risk of bias}

\begin{tabular}{lll}
\hline Bias & Authors' judgement & Support for judgement \\
\hline $\begin{array}{l}\text { Random sequence genera- } \\
\text { tion (selection bias) }\end{array}$ & Low risk & Computer program of random numbers \\
\hline $\begin{array}{l}\text { Allocation concealment } \\
\text { (selection bias) }\end{array}$ & Unclear risk & - \\
\hline $\begin{array}{l}\text { Blinding (performance } \\
\text { bias and detection bias) } \\
\text { All outcomes }\end{array}$ & Unclear risk & $\begin{array}{l}\text { Placebo solution of 20\% human albumin administered. Unclear if outcome as- } \\
\text { sessors were blinded. States it is 'double-blinded' }\end{array}$ \\
\hline $\begin{array}{l}\text { Incomplete outcome data } \\
\text { (attrition bias) } \\
\text { All outcomes }\end{array}$ & High risk & $\begin{array}{l}67 \text { children randomised of whom only 47 met the inclusion criterion of cough } \leq \\
14 \text { days }\end{array}$ \\
\hline $\begin{array}{l}\text { Selective reporting (re- } \\
\text { porting bias) }\end{array}$ & High risk & $\begin{array}{l}\text { Incomplete reporting of outcomes of interest. The 2 different immunoglobulin } \\
\text { groups were aggregated }\end{array}$ \\
\hline \begin{tabular}{l} 
Other bias \\
\hline
\end{tabular} & High risk & \begin{tabular}{l} 
Insufficient sample size. Numerous potential confounders \\
\hline
\end{tabular}
\end{tabular}

Halperin 2007

\begin{tabular}{ll}
\hline Methods & Randomisation allocated by a computer-generated list in a 2:1 ratio with a balanced block size of 6 \\
stratified by age and centre. Double-blinded, placebo-controlled. Intention-to-treat analysis was re- \\
ported
\end{tabular}

Participants

25 infants < 5 years of age (17 P-IGIV, 8 placebo). Mean age 2.3 months in P-IGIV group and 19 months in the placebo group. 4 of the P-IGIV recipients and no placebo recipients received any doses of pertussis 
Halperin 2007 (Continued)

vaccine. 6 placebo and 12 P-IGIV recipients had laboratory confirmation of pertussis. Criteria for inclusion clearly outlined

\begin{tabular}{|c|c|}
\hline Interventions & $\begin{array}{l}\text { P-IGIV (750 mg/kg) or placebo was administered as a single infusion over } 3 \text { hours; initial infusion was } \\
1.5 \mathrm{ml} / \mathrm{kg} / \mathrm{hr} \text { increasing gradually to } 6.0 \mathrm{ml} / \mathrm{kg} / \mathrm{hr}\end{array}$ \\
\hline Outcomes & $\begin{array}{l}\text { Percentage of paroxysmal cough, vomiting, whoop, apnoea, cyanosis and nasal congestion. Mean } \\
\text { slope and median events paroxysmal cough, oxygen desaturation, bradycardia, whoop and apnoea. } \\
\text { Percentage reduction in paroxysms of cough between baseline and post-treatment period ( } 48 \text { hours), } \\
\text { duration of hospital stay }\end{array}$ \\
\hline Notes & $\begin{array}{l}\text { Participants were monitored with a Physiac monitor designed for physiological variables for extended } \\
\text { periods. Microphone recorded coughs. This study was terminated prematurely due to expiration of P- } \\
\text { IGIV lots and unavailability of additional study product }\end{array}$ \\
\hline
\end{tabular}

\section{Risk of bias}

\begin{tabular}{lll}
\hline Bias & Authors' judgement & Support for judgement \\
\hline $\begin{array}{l}\text { Random sequence genera- } \\
\text { tion (selection bias) }\end{array}$ & Low risk & Computer-generated list \\
\hline $\begin{array}{l}\text { Allocation concealment } \\
\text { (selection bias) }\end{array}$ & Low risk & Centrally \\
\hline $\begin{array}{l}\text { Blinding (performance } \\
\text { bias and detection bias) } \\
\text { All outcomes }\end{array}$ & Low risk & Participants, personnel and assessor were blinded \\
\hline $\begin{array}{l}\text { Incomplete outcome data } \\
\text { (attrition bias) }\end{array}$ & Low risk & - \\
$\begin{array}{l}\text { All outcomes } \\
\text { Selective reporting (re- } \\
\text { porting bias) }\end{array}$ & Low risk & - \\
\hline $\begin{array}{l}\text { Other bias } \\
\text { High risk }\end{array}$ & Prematurely terminated due to poor recruitment and out of date product. On- \\
\hline
\end{tabular}

\section{Krantz 1985}

$\begin{array}{ll}\text { Methods } & \text { Generation of randomisation sequence before cross-over point not reported. Double-blinded, place- } \\ \text { bo-controlled, cross-over study. Assessor (investigator) was blinded. Intention-to-treat analysis was not } \\ \text { reported. } 52.9 \% \text { follow-up }\end{array}$

Participants participants, 9 evaluated. Hospitalised for young age and social reasons. Both male and female in-
patients, age range 0.1 to 2.3 years of age. Vaccination status and previous antibiotic treatment was not
reported. Patients had not been given salbutamol within 2 days of entering the trial and all had bacteri-
ological or serological confirmed diagnosis of pertussis

\begin{tabular}{ll}
\hline Interventions & Salbutamol $0.6 \mathrm{mg} / \mathrm{kg} /$ day orally in 4 doses for 2 days \\
\hline Outcomes & Number of paroxysms of cough, duration of paroxysms \\
\hline Notes & Patients given erythromycin $25 \mathrm{mg} / \mathrm{kg}$ twice a day \\
\hline
\end{tabular}


Krantz 1985 (Continued)

Risk of bias

\begin{tabular}{lll}
\hline Bias & Authors' judgement & Support for judgement \\
\hline $\begin{array}{l}\text { Random sequence genera- } \\
\text { tion (selection bias) }\end{array}$ & Unclear risk & Randomly allocated sequence \\
\hline $\begin{array}{l}\text { Allocation concealment } \\
\text { (selection bias) }\end{array}$ & Unclear risk & - \\
\hline $\begin{array}{l}\text { Blinding (performance } \\
\text { bias and detection bias) } \\
\text { All outcomes }\end{array}$ & Unclear risk & $\begin{array}{l}\text { Placebo syrup identical to active drug. Personnel blinded. Cross-over point } \\
\text { blinded. Outcomes 8pm to 7am, monitored by nurse }\end{array}$ \\
\hline $\begin{array}{l}\text { Incomplete outcome data } \\
\text { (attrition bias) } \\
\text { All outcomes }\end{array}$ & High risk & Insufficient outcome assessed. Loss of 8/17 patients \\
\hline $\begin{array}{l}\text { Selective reporting (re- } \\
\text { porting bias) }\end{array}$ & High risk & \\
\hline \begin{tabular}{l} 
Other bias \\
\hline
\end{tabular} & High risk & Primary outcomes not assessed in sufficient detail \\
\hline
\end{tabular}

Lucchesi 1949

Methods Quasi-random allocation (alternation). Blinding and intention-to-treat analysis was not reported. Loss to follow-up was unclear

\begin{tabular}{ll}
\hline Participants & $\begin{array}{l}\text { Both male and female inpatients under the age of } 1 \text { year. Vaccination status and previous antibiotic } \\
\text { treatment were not reported. Clinical and bacteriologically diagnosed pertussis }\end{array}$ \\
\hline Interventions & $\begin{array}{l}\text { Pertussis immune serum, } 50 \text { to } 100 \mathrm{ml} \text { intravenously on admission followed by } 50 \mathrm{ml} / \mathrm{day} \text { until im- } \\
\text { provement, or } 5 \text { doses }\end{array}$ \\
\hline Outcomes & Frequency of paroxysms of cough \\
\hline Notes & -
\end{tabular}

Risk of bias

\begin{tabular}{lll}
\hline Bias & Authors' judgement & Support for judgement \\
\hline $\begin{array}{l}\text { Random sequence genera- } \\
\text { tion (selection bias) }\end{array}$ & High risk & Alternate allocation \\
\hline $\begin{array}{l}\text { Allocation concealment } \\
\text { (selection bias) }\end{array}$ & High risk & $\begin{array}{l}\text { Patients divided into 2 groups; each group included the alternate patients ad- } \\
\text { mitted without selection }\end{array}$ \\
\hline $\begin{array}{l}\text { Blinding (performance } \\
\text { bias and detection bias) }\end{array}$ & High risk & No blinding of participants, personnel or assessor \\
$\begin{array}{l}\text { All outcomes } \\
\begin{array}{l}\text { Incomplete outcome data } \\
\text { (attrition bias) }\end{array}\end{array}$ & High risk \\
All outcomes & & - \\
\hline \hline
\end{tabular}


Lucchesi 1949 (Continued)

Selective reporting (re- High risk Inadequate details in protocol porting bias)

Other bias High risk Different doses given. Numerous potential confounders

Mertsola 1986

Methods Method of randomisation was not stated. Was a double-blinded study. Intention-to-treat analysis was not reported. Loss to follow-up was unclear

Participants Outpatients, all vaccinated (gender not specified) with a mean age of 9.4 years in the treatment group and 7.5 years in the control group. $14.8 \%$ received previous antibiotic treatment and all the participants had been previously vaccinated. Bacteriologically and serologically confirmed pertussis

\begin{tabular}{ll}
\hline Interventions & Salbutamol orally $0.1 \mathrm{mg} / \mathrm{kg}$ orally 3 times a day for 10 days \\
\hline Outcomes & Number of paroxysms of cough \\
\hline Notes & -
\end{tabular}

\section{Risk of bias}

\begin{tabular}{lll}
\hline Bias & Authors' judgement & Support for judgement \\
\hline $\begin{array}{l}\text { Random sequence genera- } \\
\text { tion (selection bias) }\end{array}$ & High risk & Not stated \\
\hline $\begin{array}{l}\text { Allocation concealment } \\
\text { (selection bias) }\end{array}$ & Unclear risk & $\begin{array}{l}\text { Double-blinded but no details provided. Randomised controls received a cor- } \\
\text { responding dose of placebo }\end{array}$ \\
\hline $\begin{array}{l}\text { Blinding (performance } \\
\text { bias and detection bias) } \\
\text { All outcomes }\end{array}$ & Unclear risk & $\begin{array}{l}\text { Insufficient details. Unclear if personnel were blinded or assessors were blind- } \\
\text { ed }\end{array}$ \\
\hline $\begin{array}{l}\text { Incomplete outcome data } \\
\text { (attrition bias) } \\
\text { All outcomes }\end{array}$ & Unclear risk & - \\
\hline $\begin{array}{l}\text { Selective reporting (re- } \\
\text { porting bias) }\end{array}$ & Unclear risk & Not clear if intention-to-treat \\
\hline \begin{tabular}{l} 
Other bias \\
\hline
\end{tabular} & High risk & Method of assessing outcomes not stated \\
\hline
\end{tabular}

\section{Miraglia 1984}

\begin{tabular}{ll}
\hline Methods & $\begin{array}{l}\text { Method of randomisation was unclear. A double-blind, placebo-controlled, trial. Intention-to-treat } \\
\text { analysis was not reported. } 100 \% \text { follow-up }\end{array}$ \\
\hline Participants & $\begin{array}{l}\text { Both male and female patients, age range } 12 \text { months to } 11 \text { years in the treatment group and } 10 \text { months } \\
\text { to } 12 \text { years in the control group. Vaccination status and previous antibiotic treatment were not report- } \\
\text { ed. Clinically diagnosed pertussis }\end{array}$ \\
\hline Interventions & Chlophedianol $1.62 \mathrm{mg} / \mathrm{kg} /$ day orally plus sobrerol $3.6 \mathrm{mg} / \mathrm{kg} /$ day orally \\
\hline \hline
\end{tabular}


Miraglia 1984 (Continued)

\begin{tabular}{ll} 
Outcomes & Severity of paroxysms of cough \\
\hline Notes & Placebo was a syrup base \\
\hline
\end{tabular}

\section{Risk of bias}

\begin{tabular}{|c|c|c|}
\hline Bias & Authors' judgement & Support for judgement \\
\hline $\begin{array}{l}\text { Random sequence genera- } \\
\text { tion (selection bias) }\end{array}$ & Unclear risk & Method of randomisation was not stated \\
\hline $\begin{array}{l}\text { Allocation concealment } \\
\text { (selection bias) }\end{array}$ & Unclear risk & Double-blinded but no details provided \\
\hline $\begin{array}{l}\text { Blinding (performance } \\
\text { bias and detection bias) } \\
\text { All outcomes }\end{array}$ & High risk & No indication if blinding was effective. Placebo base was a syrup (sciroppo) \\
\hline $\begin{array}{l}\text { Incomplete outcome data } \\
\text { (attrition bias) } \\
\text { All outcomes }\end{array}$ & Low risk & Sufficient details were provided to address this \\
\hline $\begin{array}{l}\text { Selective reporting (re- } \\
\text { porting bias) }\end{array}$ & Low risk & - \\
\hline Other bias & Unclear risk & $\begin{array}{l}\text { Evaluation of symptoms was subjective and based on a score sheet for staff } \\
\text { and parents to use }\end{array}$ \\
\hline
\end{tabular}

\section{Pavesio 1977}

\begin{tabular}{ll}
\hline Methods & $\begin{array}{l}\text { Method of randomisation was not stated. Placebo-controlled trial. Intention-to-treat analysis was not } \\
\text { reported. Follow-up unclear }\end{array}$
\end{tabular}
reported. Follow-up unclear

Participants $\begin{aligned} & \text { Inpatients (gender not specified), age range } 6 \text { months to } 3 \text { years, coughing for less than } 21 \text { days. None } \\ & \text { had been previously vaccinated. Previous antibiotic treatment was not reported. Clinically diagnosed } \\ & \text { pertussis. Recruited between September } 1975 \text { and October } 1976\end{aligned}$
pertussis. Recruited between September 1975 and October 1976

\begin{tabular}{ll}
\hline Interventions & Salbutamol $0.5 \mathrm{mg} / \mathrm{kg} /$ day orally in 3 doses for 15 days \\
\hline Outcomes & Frequency of paroxysms of cough, frequency of whoops \\
\hline Notes & Erythromycin oral $40 \mathrm{mg} / \mathrm{kg} /$ day for 10 days. Placebo saccharin
\end{tabular}

\section{Risk of bias}

\begin{tabular}{lll}
\hline Bias & Authors' judgement & Support for judgement \\
\hline $\begin{array}{l}\text { Random sequence genera- } \\
\text { tion (selection bias) }\end{array}$ & High risk & Appears to have used 'random' allocation in unspecified way \\
\hline $\begin{array}{l}\text { Allocation concealment } \\
\text { (selection bias) }\end{array}$ & High risk & Insufficient details reported \\
\hline $\begin{array}{l}\text { Blinding (performance } \\
\text { bias and detection bias) }\end{array}$ & High risk & $\begin{array}{l}\text { Placebo syrup was saccharin. Unclear if participants, personnel or assessors } \\
\text { were blinded }\end{array}$ \\
\hline
\end{tabular}


Pavesio 1977 (Continued)

All outcomes

\begin{tabular}{lll}
\hline $\begin{array}{l}\text { Incomplete outcome data } \\
\text { (attrition bias) } \\
\text { All outcomes }\end{array}$ & High risk & Data not reported in a way to assess this \\
\hline $\begin{array}{l}\text { Selective reporting (re- } \\
\text { porting bias) }\end{array}$ & High risk & Data not reported in a way to assess this \\
\hline Other bias & High risk & Unclear how outcomes were measured \\
\hline
\end{tabular}

\section{Roberts 1992}

\begin{tabular}{ll}
\hline Methods & $\begin{array}{l}\text { Method of randomisation was not stated (hospital pharmacy was responsible for assignment of pa- } \\
\text { tients to treatment groups). Was a double-blind, placebo-controlled trial. Intention-to-treat analysis } \\
\text { was not reported. } 100 \% \text { follow-up }\end{array}$ \\
\hline Participants & $\begin{array}{l}\text { Inpatients (gender not specified) less than } 6 \text { months of age. Vaccination status and previous antibiotic } \\
\text { treatment were not reported. Clinically diagnosed pertussis }\end{array}$ \\
\hline Interventions & Dexamethasone $0.3 \mathrm{mg} / \mathrm{kg} /$ day for 4 days. Route of administration not stated \\
\hline Outcomes & $\begin{array}{l}\text { Percentage reduction in paroxysms of cough between baseline and post-treatment period (48 hours), } \\
\text { duration of hospital stay }\end{array}$ \\
\hline Notes & Erythromycin $40 \mathrm{mg} / \mathrm{kg} / \mathrm{day}$ for 14 days
\end{tabular}

\section{Risk of bias}

\begin{tabular}{lll}
\hline Bias & Authors' judgement & Support for judgement \\
\hline $\begin{array}{l}\text { Random sequence genera- } \\
\text { tion (selection bias) }\end{array}$ & Unclear risk & Method of randomisation not stated. 7 patients in intervention, 4 in control \\
\hline $\begin{array}{l}\text { Allocation concealment } \\
\text { (selection bias) }\end{array}$ & Unclear risk & Central randomisation by hospital pharmacy \\
\hline $\begin{array}{l}\text { Blinding (performance } \\
\text { bias and detection bias) } \\
\text { All outcomes }\end{array}$ & Unclear risk & $\begin{array}{l}\text { Used placebo but no details provided. Not stated if participant, personnel or } \\
\text { assessors were blinded }\end{array}$ \\
\hline $\begin{array}{l}\text { Incomplete outcome data } \\
\text { (attrition bias) }\end{array}$ & High risk & \\
$\begin{array}{l}\text { All outcomes } \\
\text { Selective reporting (re- } \\
\text { porting bias) }\end{array}$ & Unclear risk & Insufficient details provided \\
\hline \begin{tabular}{l} 
Other bias \\
\hline
\end{tabular} & Unclear risk & Unclear how outcomes measured \\
\hline
\end{tabular}


Wang 2014

Methods

Double-blind, randomised, placebo-controlled trial. The randomisation sequence was computer-generated by an independent statistician and stratified by general practice with a fixed block size of 4 . Primary analysis was by intention-to-treat with last observation carried forward

Participants

276 non-smoking adults aged 16 to 49 years who presented in primary care with a postinfectious cough of 2 to 8 weeks' duration, of whom 70 had laboratory-confirmed pertussis. Recruited between April 2011 and September 2012. Laboratory-confirmed pertussis was diagnosed in participants with an oral fluid anti-pertussis toxin IgG titre of 70 arbitrary units or higher. Inclusion and exclusion criteria clearly described

Interventions

Montelukast sodium $10 \mathrm{mg}$ tablets or image-matched placebo tablets (main excipient lactose monohydrate) for 14 days. Participants chose whether to continue taking study medication after 2 weeks

Outcomes

The primary outcomes were changes in cough-specific quality of life after 2 weeks and 4 weeks. Coughspecific quality of life was measured using the Leicester Cough Questionnaire, which participants completed at baseline, 2 weeks and 4 weeks. Paroxysmal cough severity was a secondary outcome measured by calculating the area under the curve for participant diary recordings of the number of paroxysms of cough per day during the 2-week period post-randomisation

Notes Adjusted analyses in the subgroup with laboratory-confirmed pertussis were adjusted for baseline scores

\section{Risk of bias}

\begin{tabular}{|c|c|c|}
\hline Bias & Authors' judgement & Support for judgement \\
\hline $\begin{array}{l}\text { Random sequence genera- } \\
\text { tion (selection bias) }\end{array}$ & Low risk & $\begin{array}{l}\text { The randomisation sequence was computer-generated by an independent sta- } \\
\text { tistician }\end{array}$ \\
\hline $\begin{array}{l}\text { Allocation concealment } \\
\text { (selection bias) }\end{array}$ & Low risk & $\begin{array}{l}\text { Montelukast and placebo tablets and medication bottles were identical in ap- } \\
\text { pearance. The randomisation sequence was retained by an independent sta- } \\
\text { tistician }\end{array}$ \\
\hline $\begin{array}{l}\text { Blinding (performance } \\
\text { bias and detection bias) } \\
\text { All outcomes }\end{array}$ & Low risk & $\begin{array}{l}\text { Participants, healthcare professionals and research staff were blinded to treat- } \\
\text { ment allocation. All data were collected and analysed blinded to treatment al- } \\
\text { location }\end{array}$ \\
\hline $\begin{array}{l}\text { Incomplete outcome data } \\
\text { (attrition bias) } \\
\text { All outcomes }\end{array}$ & Low risk & $\begin{array}{l}\text { No significant differences in attrition rates between groups were observed } \\
\text { after } 2 \text { weeks (montelukast } 11 / 137 \text { participants, } 8.0 \% \text {; placebo } 13 / 139 \text { par- } \\
\text { ticipants, } 9.4 \% \text {, P value }=0.70 \text { ) or } 4 \text { weeks (montelukast } 15 / 137 \text { participants, } \\
11.0 \% \text {; placebo } 16 / 139 \text { participants, } 11.5 \%, P \text { value }=0.88 \text { ) }\end{array}$ \\
\hline $\begin{array}{l}\text { Selective reporting (re- } \\
\text { porting bias) }\end{array}$ & Low risk & $\begin{array}{l}\text { Results were reported in the intention-to-treat population. Missing data were } \\
\text { imputed by last observation carried forward }\end{array}$ \\
\hline Other bias & Low risk & $\begin{array}{l}\text { Findings may not be generalisable to smokers, children under } 16 \text { years of age } \\
\text { and adults over } 49 \text { years of age. However, authors acknowledge this and ex- } \\
\text { plain rationale for these study eligibility criteria }\end{array}$ \\
\hline
\end{tabular}

Zoumboulakis 1973

$\begin{array}{ll}\text { Methods } & \text { Quasi-random allocation (alternation). Stated that an observer was blinded. Intention-to-treat analysis } \\ \text { was not reported. } 94.5 \% \text { follow-up. No placebo stated }\end{array}$


Zoumboulakis 1973 (Continued)

Participants Both male and female inpatients coughing for less than 3 weeks. Recruited between November 1968 and May 1971. Age range of 15 days to 3 years. $92.7 \%$ were not previously vaccinated and $7.3 \%$ had incomplete vaccination. None had previous antibiotic treatment. Clinically diagnosed pertussis

\begin{tabular}{ll}
\hline Interventions & Hydrocortisone $30 \mathrm{mg} / \mathrm{kg} /$ day intramuscularly for 2 days followed by a reduced dosage over 6 days \\
\hline Outcomes & Mean number of paroxysms of cough, mean number of whoops, mean number of vomits \\
\hline Notes & $\begin{array}{l}\text { Erythromycin given orally } 40 \mathrm{mg} / \mathrm{kg} / \text { day for } 10 \text { days. Coughing episodes assessed and scored by blind- } \\
\text { ed nurse }\end{array}$
\end{tabular}

\section{Risk of bias}

\begin{tabular}{lll}
\hline Bias & Authors' judgement & Support for judgement \\
\hline $\begin{array}{l}\text { Random sequence genera- } \\
\text { tion (selection bias) }\end{array}$ & High risk & Alternate allocation \\
\hline $\begin{array}{l}\text { Allocation concealment } \\
\text { (selection bias) }\end{array}$ & High risk & Baseline characteristics differ between groups \\
\hline $\begin{array}{l}\text { Blinding (performance } \\
\text { bias and detection bias) } \\
\text { All outcomes }\end{array}$ & High risk & $\begin{array}{l}\text { No blinding of participants, assessors apparently blinded, unclear if personnel } \\
\text { were blinded }\end{array}$ \\
\hline $\begin{array}{l}\text { Incomplete outcome data } \\
\text { (attrition bias) } \\
\text { All outcomes }\end{array}$ & Unclear risk & Insufficient details reported to assess this \\
\hline $\begin{array}{l}\text { Selective reporting (re- } \\
\text { porting bias) }\end{array}$ & Low risk & - \\
\hline \begin{tabular}{l} 
Other bias \\
\hline
\end{tabular} & High risk & Unclear how outcomes were measured \\
\hline
\end{tabular}

CDC: Centers for Disease Control and Prevention

P-IGIV: intravenous pertussis immunoglobulin

WHO: World Health Organization

Characteristics of excluded studies [ordered by study ID]

\begin{tabular}{ll}
\hline Study & Reason for exclusion \\
\hline Ames 1953 & $\begin{array}{l}\text { Sampling was reported as 'using the lottery method' (implying chance allocation to treatment } \\
\text { groups). Gross baseline imbalances between groups appeared unlikely to be due to random alloca- } \\
\text { tion and in any event a fatal flaw in validity }\end{array}$ \\
\hline Badr-El-Din 1976 & $\begin{array}{l}\text { Patients were randomly allocated to 1) chloramphenicol, 2) chloramphenicol and prednisone or 3) } \\
\text { chloramphenicol and salbutamol. Large baseline differences were reported between the chloram- } \\
\text { phenicol only group and the other 2 treatment groups. No explanation was given for having } 2 \text { chlo- } \\
\text { ramphenicol groups }\end{array}$ \\
\hline Balagtas 1971 & $\begin{array}{l}\text { Random allocation was abandoned during an epidemic when all patients were immunised. Data } \\
\text { for randomly allocated patients before the epidemic were not reported }\end{array}$ \\
\hline
\end{tabular}




\begin{tabular}{|c|c|}
\hline Study & Reason for exclusion \\
\hline Bertaggia 1972 & $\begin{array}{l}\text { Random allocation unclear, no allocation concealment stated or blinding of participants or per- } \\
\text { sonnel. Study performed over an 8-year period }\end{array}$ \\
\hline Brunskill 1986 & $\begin{array}{l}\text { Allocation method unclear, no direct comparison of treatment and control. Graphical represen- } \\
\text { tation of the allocation sequence in the results was not consistent with allocation sequence de- } \\
\text { scribed in the text }\end{array}$ \\
\hline Bruss 1999 & $\begin{array}{l}\text { Comparison of } 2 \text { doses of pertussis immunoglobulin without comparison with placebo or no treat- } \\
\text { ment }\end{array}$ \\
\hline Chandra 1972 & Method of allocation not stated \\
\hline Eichlseder 1963 & $\begin{array}{l}\text { Patients assigned in an alternating manner to either (chloramphenicol succinate) or (chloram- } \\
\text { phenicol and pertussis-immunoglobulin) or (pertussis-immunoglobulin and oxytetracycline). The } \\
\text { only control group was for chloramphenicol succinate. Alternating system to allocate patients } \\
\text { stated to be age to intervention }\end{array}$ \\
\hline Giuliani 1966 & $\begin{array}{l}\text { Random allocation unclear, no allocation concealment stated or blinding of participants or per- } \\
\text { sonnel. Methods unclear. Study performed over a } 10 \text {-year period }\end{array}$ \\
\hline Leen 1989 & $\begin{array}{l}\text { Randomisation performed by random code. No placebo. Another intervention stated to be used for } \\
\text { children with complications but no details provided or number of children with extra intervention }\end{array}$ \\
\hline Lewis 1984 & $\begin{array}{l}\text { No head-to-head comparison was made between the group receiving Drosera and the group re- } \\
\text { ceiving Sac Lac. Positive or negative response to treatment was determined subjectively by par- } \\
\text { ents. Effectively a before-after study with the patients in "treatment group A" that received Sac Lac } \\
\text { compared with the non-responders in 'treatment group B' }\end{array}$ \\
\hline Musso 1982 & $\begin{array}{l}\text { No allocation sequence generated, no allocation concealment or blinding stated. Control and in- } \\
\text { tervention group received antibiotic and pertussis immunoglobulin treatment prior to other inter- } \\
\text { vention }\end{array}$ \\
\hline Pavesio 1979 & Controlled trial with no random allocation and no mention of methods \\
\hline Sacchetti 1982 & Allocation method unclear, no direct comparison of treatment and control \\
\hline Torre 1993 & $\begin{array}{l}\text { No allocation sequence generated, no allocation concealment or blinding stated. No controls stat- } \\
\text { ed }\end{array}$ \\
\hline
\end{tabular}

\section{DATA AND ANALYSES}

\section{Comparison 1. Antihistamines versus placebo}

\begin{tabular}{lllll}
\hline Outcome or subgroup title & $\begin{array}{l}\text { No. of } \\
\text { studies }\end{array}$ & $\begin{array}{l}\text { No. of par- } \\
\text { ticipants }\end{array}$ & Statistical method & Effect size \\
\hline 1 Paroxysms of cough per 24 hours & 1 & Mean Difference (IV, Random, 95\% Cl) & Subtotals only \\
\hline
\end{tabular}


Analysis 1.1. Comparison 1 Antihistamines versus placebo, Outcome 1 Paroxysms of cough per 24 hours.

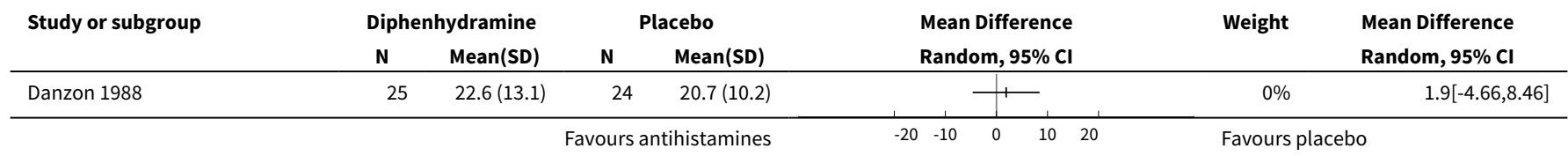

Comparison 2. Pertussis immunoglobulin versus placebo

\begin{tabular}{lllll}
\hline Outcome or subgroup title & $\begin{array}{l}\text { No. of } \\
\text { studies }\end{array}$ & $\begin{array}{l}\text { No. of } \\
\text { partici- } \\
\text { pants }\end{array}$ & Statistical method & Effect size \\
\hline 1 Mean paroxysmal cough per hour & 1 & $\begin{array}{l}\text { Mean Difference (IV, Random, } \\
95 \% \text { Cl) }\end{array}$ & Subtotals only \\
\hline 2 Mean number of whoops per day (first week) & 1 & $\begin{array}{l}\text { Mean Difference (IV, Random, } \\
95 \% \text { Cl) }\end{array}$ & Subtotals only \\
\hline 3 Mean whoops per hour & 1 & $\begin{array}{l}\text { Mean Difference (IV, Random, } \\
95 \% \text { Cl) }\end{array}$ & Subtotals only \\
\hline 4 Duration of hospital stay (days) & 1 & $\begin{array}{l}\text { Mean Difference (IV, Random, } \\
95 \% \text { Cl) }\end{array}$ & Subtotals only \\
\hline
\end{tabular}

Analysis 2.1. Comparison 2 Pertussis immunoglobulin versus placebo, Outcome 1 Mean paroxysmal cough per hour.

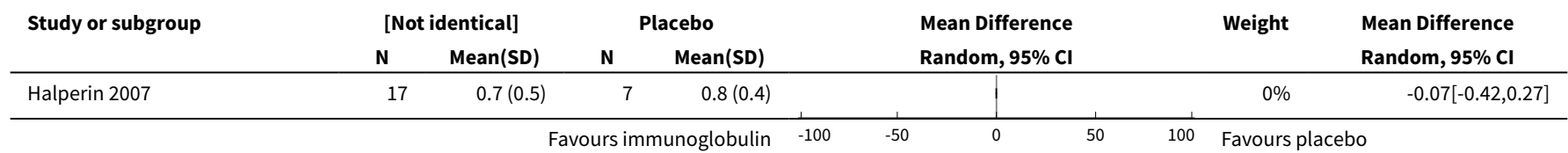

Analysis 2.2. Comparison 2 Pertussis immunoglobulin versus placebo, Outcome 2 Mean number of whoops per day (first week).

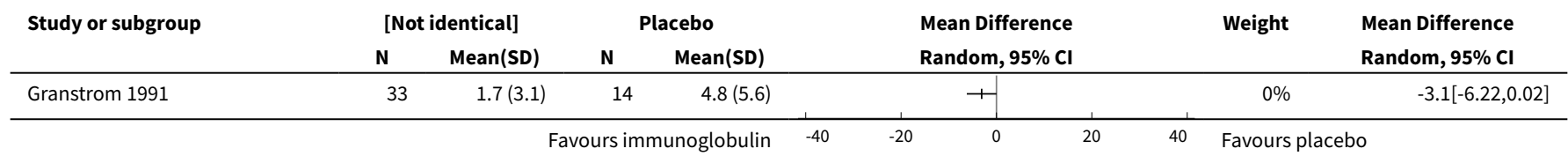

Analysis 2.3. Comparison 2 Pertussis immunoglobulin versus placebo, Outcome 3 Mean whoops per hour.

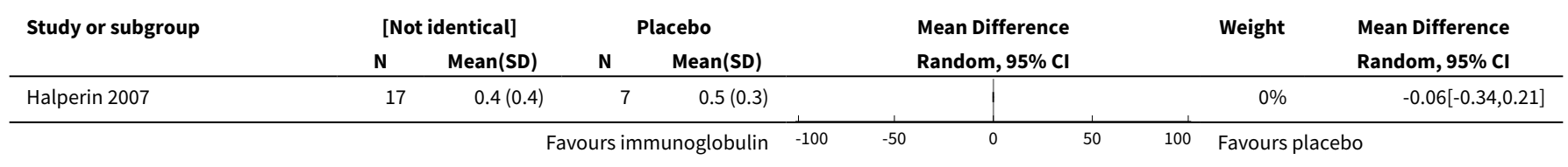


Analysis 2.4. Comparison 2 Pertussis immunoglobulin versus placebo, Outcome 4 Duration of hospital stay (days).

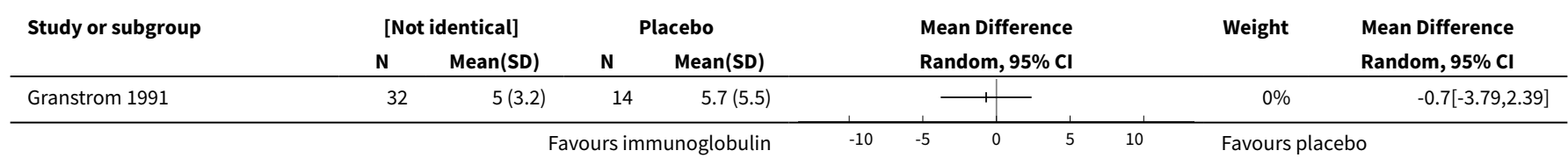

\section{Comparison 3. Salbutamol versus placebo}

\begin{tabular}{llllll}
\hline Outcome or subgroup title & $\begin{array}{l}\text { No. of } \\
\text { studies }\end{array}$ & $\begin{array}{l}\text { No. of par- } \\
\text { ticipants }\end{array}$ & Statistical method & Effect size \\
\hline 1 Paroxysms of cough per day & 2 & 42 & Mean Difference (IV, Fixed, 95\% CI) & $-0.22[-4.13,3.69]$ \\
\hline
\end{tabular}

Analysis 3.1. Comparison 3 Salbutamol versus placebo, Outcome 1 Paroxysms of cough per day.

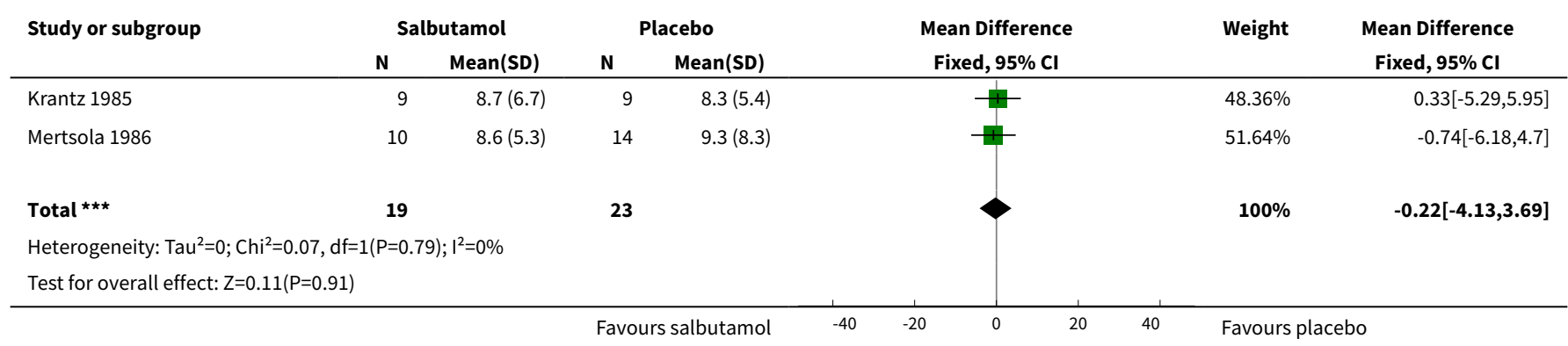

\section{Comparison 4. Steroids versus placebo}

\begin{tabular}{lllll}
\hline Outcome or subgroup title & $\begin{array}{l}\text { No. of } \\
\text { studies }\end{array}$ & $\begin{array}{l}\text { No. of par- } \\
\text { ticipants }\end{array}$ & Statistical method & Effect size \\
\hline 1 Duration of hospital stay (days) & 1 & & Mean Difference (IV, Random, 95\% CI) & Subtotals only \\
\hline
\end{tabular}

Analysis 4.1. Comparison 4 Steroids versus placebo, Outcome 1 Duration of hospital stay (days).

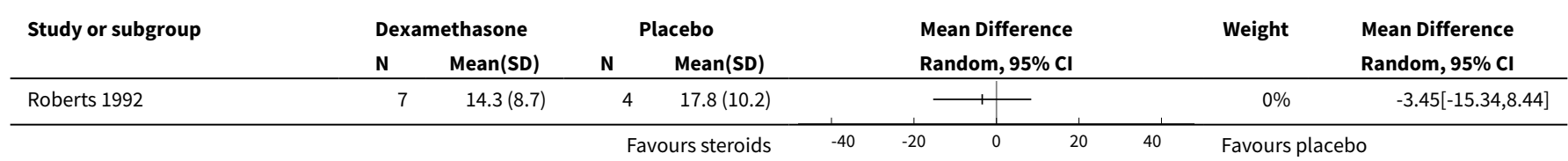

\section{ADDITIONAL TABLES}


Table 1. Treatments compared with placebo for symptoms of whooping cough

\begin{tabular}{|c|c|c|c|c|}
\hline \multicolumn{5}{|c|}{ Treatments compared with placebo for symptoms of whooping cough } \\
\hline \multicolumn{5}{|c|}{$\begin{array}{l}\text { Patient or population: children and adults with clinically diagnosed or laboratory-confirmed whooping cough } \\
\text { Settings: hospital inpatient and community healthcare settings }\end{array}$} \\
\hline \multicolumn{5}{|c|}{ Intervention: diphenhydramine, salbutamol, pertussis immunoglobulin, dexamethasone } \\
\hline \multicolumn{5}{|l|}{ Comparison: placebo } \\
\hline \multirow[t]{2}{*}{ Outcomes } & \multicolumn{2}{|c|}{$\begin{array}{l}\text { Mean (standard devia- } \\
\text { tion) }\end{array}$} & \multirow[t]{2}{*}{$\begin{array}{l}\text { Mean difference } \\
(95 \% \mathrm{Cl})\end{array}$} & \multirow{2}{*}{$\begin{array}{l}\text { No. of } \\
\text { partici- } \\
\text { pants } \\
\text { (studies) }\end{array}$} \\
\hline & Treatment & Placebo & & \\
\hline Paroxysms of cough per 24 hours (diphenhydramine) & $22.6(13.1)$ & $20.7(10.2)$ & $1.90(-4.66$ to 8.46$)$ & $49(1)$ \\
\hline Paroxysms of cough per day (salbutamol) & * & * & $-0.22(-4.13$ to 3.69$)$ & $42(2)$ \\
\hline $\begin{array}{l}\text { Mean paroxysmal cough per hour (pertussis im- } \\
\text { munoglobulin) }\end{array}$ & $0.73(0.46)$ & $0.81(0.36)$ & $-0.07(-0.42$ to 0.27$)$ & $24(1)$ \\
\hline Mean whoops per hour (pertussis immunoglobulin) & $0.39(0.38)$ & $0.46(0.28)$ & $-0.06(-0.34$ to 0.21$)$ & $24(1)$ \\
\hline $\begin{array}{l}\text { Duration of hospital stay, days (pertussis immunoglob- } \\
\text { ulin) }\end{array}$ & $5(3.2)$ & $5.7(5.5)$ & $-0.70(-3.79$ to 2.39$)$ & $46(1)$ \\
\hline Duration of hospital stay, days (dexamethasone) & $14.3(8.7)$ & $17.8(10.2)$ & $-3.45(-15.34$ to 8.44$)$ & $11(1)$ \\
\hline
\end{tabular}

*See Analysis 3.1

Cl: Confidence interval

Table 2. Results for pre-specified outcomes reported in included studies

\begin{tabular}{|c|c|c|c|}
\hline Study ID & $\begin{array}{l}\text { Interven- } \\
\text { tion }\end{array}$ & Outcomes & Results \\
\hline Ghaffari 2011 & $\begin{array}{l}\text { Tramadol } \\
50 \text { mg daily } \\
\text { from days } 1 \\
\text { to } 5\end{array}$ & $\begin{array}{l}\text { Severity of } \\
\text { whooping } \\
\text { cough }\end{array}$ & $\begin{array}{l}\text { The number of participants with severe pertussis in the intervention arm decreased } \\
\text { from } 16(53.3 \%) \text { before treatment to } 7(23.3 \%) \text { after treatment but remained almost } \\
\text { unchanged in the control arm ( } 17(56.7 \%) \text { before treatment versus } 16 \text { ( } 53.3 \%) \text { after } \\
\text { treatment). The number of participants with moderate pertussis decreased from } 14 \\
\text { (46.7\%) before treatment to } 6(20 \%) \text { after treatment in the intervention arm, but on- } \\
\text { ly from } 13(43.3 \%) \text { before treatment to } 10(33.3 \%) \text { after treatment in the control arm. } \\
\text { Severe and moderate pertussis were diagnosed using a questionnaire scoring sys- } \\
\text { tem based on Centers for Disease Control and Prevention (CDC) and World Health } \\
\text { Organization (WHO) clinical case definitions of pertussis. Drowsiness was reported } \\
\text { as a side effect in } 1 \text { patient in the intervention arm. No side effects were reported in } \\
\text { the control arm }\end{array}$ \\
\hline $\begin{array}{l}\text { Lucchesi } \\
1949\end{array}$ & $\begin{array}{l}\text { Pertussis im- } \\
\text { mune serum } \\
50 \text { to } 100 \\
\mathrm{ml} \text { on ad- } \\
\text { mission fol- } \\
\text { lowed by } 50\end{array}$ & $\begin{array}{l}\text { Frequency of } \\
\text { paroxysms } \\
\text { of cough }\end{array}$ & $\begin{array}{l}\text { Results were presented graphically as means of means of } 7 \text {-day periods - unable to } \\
\text { extract data from the graphs provided } \\
\text { As described by previous authors (Pillay 2003), the conclusion (from visual inspec- } \\
\text { tion of graphs) - "The patients who received serum showed a more regular decline } \\
\text { in the rate of frequency of paroxysms when treated in the first week of disease than } \\
\text { did the patients in the control group" }\end{array}$ \\
\hline
\end{tabular}


Table 2. Results for pre-specified outcomes reported in included studies (Continued)

$\mathrm{ml}$ daily un-

til improve-

ment or 5

doses
Side effects were not reported

\author{
Frequency of Data presented graphically \\ paroxysms Extracted from graphs $\mathrm{N}=50$ \\ of cough, fre- \\ quency of \\ Mean number of episodes of cough per 24 hours (day 2 only) \\ Salbutamol -8.5 \\ Placebo - 12.3
}

Mean number of episodes of whoop per 24 hours (day 2 only)

Salbutamol - 2.0

Placebo - 6.1

Side effects were not reported
Semi-quantitative score of severity of paroxysms - scale of 0 to 4

$\mathrm{N}=15$

Chlophedianol and sobrerol -0.80

Placebo - 1.3

Side effect reported was diarrhoea in $6.7 \%$ of the placebo group. Authors stated that the diarrhoea was not related to being a part of the study as event of diarrhoea was recorded 2 days after treatment with placebo

\begin{tabular}{|c|c|c|c|}
\hline Wang 2014 & $\begin{array}{l}\text { Montelukast } \\
\text { sodium } \\
10 \text { mg dai- } \\
\text { ly for } 14 \\
\text { days; partici- } \\
\text { pants chose } \\
\text { whether to } \\
\text { continue } \\
\text { study med- } \\
\text { ication after } \\
2 \text { weeks }\end{array}$ & $\begin{array}{l}\text { Severity of } \\
\text { paroxysms } \\
\text { of cough }\end{array}$ & 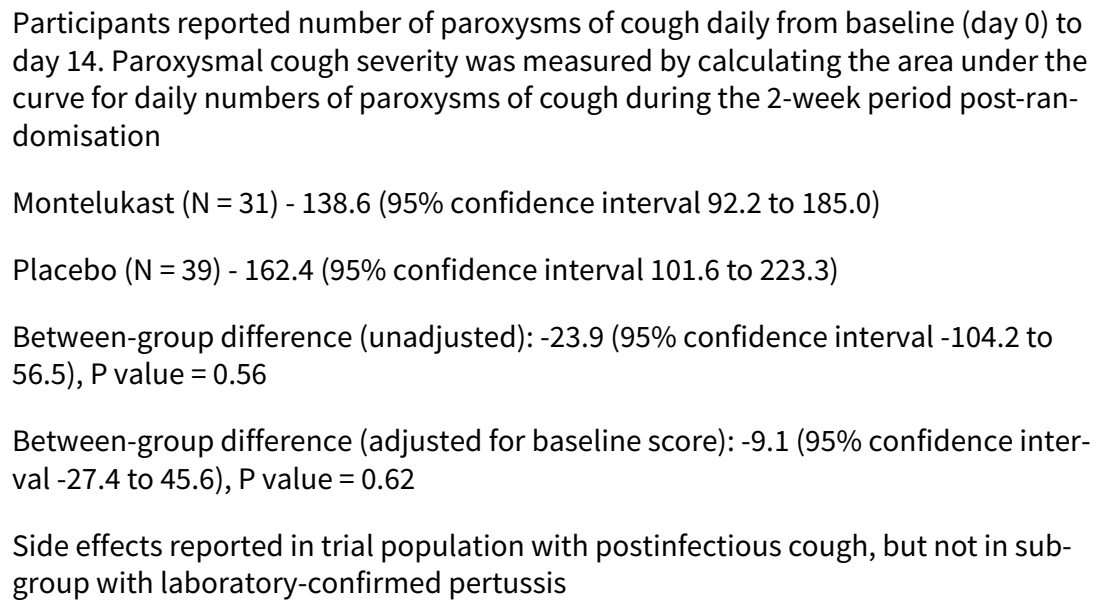 \\
\hline $\begin{array}{l}\text { Zoum- } \\
\text { boulakis } \\
1973\end{array}$ & $\begin{array}{l}\text { Hydrocorti- } \\
\text { sone } 30 \mathrm{mg} / \\
\mathrm{kg} / \text { day for } \\
2 \text { days fol- } \\
\text { lowed by } \\
\text { a reduced } \\
\text { dosage over } \\
6 \text { days }\end{array}$ & $\begin{array}{l}\text { Number of } \\
\text { paroxysms } \\
\text { of cough, } \\
\text { number of } \\
\text { whoops, } \\
\text { number of } \\
\text { vomits }\end{array}$ & $\begin{array}{l}\text { Data presented graphically } \\
\mathrm{N}=135 \\
\text { Mean number of episodes of cough per } 24 \text { hours (day } 2 \text { only) } \\
\text { Hydrocortisone - } 16 \\
\text { No treatment - } 17.9 \\
\text { Mean number of episodes of whoop per } 24 \text { hours (day } 2 \text { only) } \\
\text { Hydrocortisone - } 7 \\
\text { No treatment - } 7.8 \\
\text { Mean number of episodes of vomiting per } 24 \text { hours (day } 2 \text { only) } \\
\text { Hydrocortisone - } 4 \\
\text { No treatment - } 4\end{array}$ \\
\hline
\end{tabular}


Table 2. Results for pre-specified outcomes reported in included studies (Continued)

Side effects reported were pulmonary infiltrates in $15.1 \%$ of the hydrocortisone group and $10.7 \%$ of the control group

\section{A P PE N DICES}

\section{Appendix 1. EMBASE search strategy}

1. $\left(\right.$ whoop $^{\star}$ or pertus $\left.{ }^{\star}\right)$.tw.

2. Pertussis/

3. Bordetella pertussis/

4. 1 or 3 or 2

5. exp Vaccine/

6. exp Antibiotic Agent/

7.5 or 6

8. $4 \operatorname{not} 7$

9. Salbutamol/ or Ipratropium Bromide/

10. (salbutamol or albuterol or ventmax or ventolin or volmax or airomir or asmasal or salamol or salbulin).tw.

11. beta agonist*.tw.

12. Beta Adrenergic Receptor Stimulating Agent/

13. (inhaler ${ }^{\star}$ or nebuliser ${ }^{\star}$ or nebulizer ${ }^{\star}$ or bronchodilator $^{\star}$ or vaporiser ${ }^{\star}$ or vaporizer $^{\star}$ ).tw.

14. exp inhaler/ or nebulizer/

15. Bronchodilating Agent/ or Bronchodilation/

16. (steroid* or corticosteroid $^{\star}$ or corticoid* or glucocorticoid* or cortison* or prednisone or prednisolone or hydrocortisone).tw.

17. exp Steroid/

18. (mucolytic ${ }^{\star}$ or carbocisteine or erdosteine or erdotin or mecysteine or methyl cysteine or visclair or mucoactive).tw.

19. exp Mucolytic Agent/ or exp Antitussive Agent/

20. (cough adj5 suppress*).tw.

21. (antitussive or anti tussive or protussive or pro tussive).tw.

22. codeine.tw.

23. (cough adj5 (remed ${ }^{\star}$ or therap ${ }^{\star}$ or treatment ${ }^{\star}$ or management or medicine ${ }^{\star}$ or medication $\left.\left.{ }^{\star}\right)\right) . t w$.

24. (pholocodine or dextromethorphan or linctus).tw.

25. (demulcent ${ }^{\star}$ or ipecacauanha or expectorant $\left.{ }^{\star}\right)$.tw.

26. (decongestant ${ }^{\star}$ or ephedrine or oxymetazoline or phenylephrine or pseudoephrine or xylometazoline).tw.

27. (sudafed or galpseud or galenphol or benylin or calpol or tixulix or robitussin or galsud or actifed or vicks).tw.

28. (sedative* or diazepam or phenobarbitone or phenobarbital or chlorpromazine or largactil).tw. 
29. (benadryl or diphenhydramide or promethazine or brompheniramine or chlorphenamine or doxylamine or triprolidine or chlorphenizamine or phenergan or piriton or anti histamine ${ }^{\star}$ or antihistamin* or histamine antagonist $\left.{ }^{\star}\right)$.tw.

30. (sedat* or diazepam or phenobarbitone or phenobarbitol or chlorpromazine or largactil).tw.

31. exp Hypnotic Sedative Agent/

32. exp Antihistaminic Agent/

33. (honey or glycerol or zinc or glycerin).tw.

34. Honey/

35. exp Glycerol/

36. (anticholinergic adj (drug or agent ${ }^{\star}$ or therap*)).tw.

37. cholinergic antagonist ${ }^{\star}$. tw.

38. exp Cholinergic Receptor Blocking Agent/

39. Levdropropizine/

40. levodropropizine.tw.

41. Moguisteine/

42. moguisteine.tw.

43. ipratropium bromide.tw.

44. or/9-43

45.4 and 44

46. 8 or 45

47. limit 46 to "treatment ( 2 or more terms high sensitivity)"

Appendix 2. CINAHL search strategy

\begin{tabular}{ll}
\hline Search ID \# & Search Terms \\
\hline S44 & S8 or S42 (Limiters - Clinical Queries: Therapy - High Sensitivity) \\
\hline S43 & S8 or S42 \\
\hline S42 & S4 and S41 \\
\hline S41 & $\begin{array}{l}\text { S9 or S10 or S11 or S12 or S13 or S14 or S15 or S16 or S17 or S18 or S19 or S20 or S21 or S22 or S23 } \\
\text { or S24 or S25 or S26 or S27 or S28 or S29 or S30 or S31 or S32 or S33 or S34 or S35 or S36 or S37 or }\end{array}$ \\
\hline S40 38 or S39 or S40 \\
\hline S39 & $\begin{array}{l}\text { TI levodropropizine or AB levodropropizine or TI ipratropium bromide or AB ipratropium bromide } \\
\text { or TI moguisteine or AB moguisteine }\end{array}$ \\
\hline S38 & (MH "Cholinergic Antagonists+") \\
\hline
\end{tabular}


S37 TI (anticholinergic drug or anticholinergic agent* or anticholinergic therap ${ }^{\star}$ ) or AB ( anticholinergic drug or anticholinergic agent* or anticholinergic therap* ${ }^{\star}$ )

\begin{tabular}{ll}
\hline S36 & $\begin{array}{l}\text { TI ( sedat* or diazepam or phenobarbitone or phenobarbitol or chlorpromazine or largactil ) or AB } \\
\text { (sedat* or diazepam or phenobarbitone or phenobarbitol or chlorpromazine or largactil ) }\end{array}$ \\
\hline S35 & (MH "Hypnotics and Sedatives+") \\
\hline S34 & TI ( honey or glycerol or zinc or glycerin ) or AB ( honey or glycerol or zinc or glycerin ) \\
\hline S33 & (MH "Zinc") or (MH "Zinc Compounds+") \\
\hline S32 31 & (MH "Glycerin+") \\
\hline
\end{tabular}

TI ( benadryl or diphenhydramide or promethazine or brompheniramine or chlorphenamine or doxylamine or triprolidine or chlorphenizamine or phenergan or piriton or anti histamine* or antihistamin* or histamine antagonist* ) or AB ( benadryl or diphenhydramide or promethazine or brompheniramine or chlorphenamine or doxylamine or triprolidine or chlorphenizamine or phenergan or piriton or anti histamine* or antihistamin* or histamine antagonist* )

\begin{tabular}{ll}
\hline S29 & (MH "Histamine Antagonists+") \\
\hline S28 & $\begin{array}{l}\text { TI cough N5 remed }{ }^{\star} \text { or AB cough N5 therap* or TI cough N5 therap* or AB cough N5 treatment* or TI } \\
\text { cough N5 treatment* or AB cough N5 medicine* or TI cough N5 medicine* or AB cough N5 medica- } \\
\text { tion* or TI cough N5 medication* or AB cough N5 remed }\end{array}$ \\
\hline S27 & $\begin{array}{l}\text { TI ( sudafed or galpseud or galenphol or benylin or calpol or tixulix or robitussin or galsud or act- } \\
\text { ifed or vicks ) or AB ( sudafed or galpseud or galenphol or benylin or calpol or tixulix or robitussin or } \\
\text { galsud or actifed or vicks ) }\end{array}$
\end{tabular}

TI ( decongestant* or ephedrine or oxymetazoline or phenylephrine or pseudoephrine or xylometazoline ) or $A B$ ( decongestant* or ephedrine or oxymetazoline or phenylephrine or pseudoephrine or xylometazoline )

S25 TI ( demulcent* or ipecacauanha or expectorant ${ }^{\star}$ ) or AB ( demulcent ${ }^{\star}$ or ipecacauanha or expectorant $\left.^{*}\right)$

S24 (pholocodine or dextromethorphan or linctus) or AB (pholocodine or dextromethorphan or
linctus)

\begin{tabular}{ll}
\hline S23 & TI codeine or AB codeine \\
\hline S22 & $\begin{array}{l}\text { TI ( antitussive or anti tussive or protussive or pro tussive ) or AB ( antitussive or anti tussive or pro- } \\
\text { tussive or pro tussive ) }\end{array}$ \\
\hline S21 & (MH "Antitussive Agents +") \\
\hline S20 & TI cough N5 suppress* or AB cough N5 suppress \\
\hline S19 & $\begin{array}{l}\text { TI ( mucolytic* or carbocisteine or erdosteine or erdotin or mecysteine or methyl cysteine or vis- } \\
\text { clair or mucoactive ) or AB ( mucolytic or carbocisteine or erdosteine or erdotin or mecysteine or } \\
\text { methyl cysteine or visclair or mucoactive ) }\end{array}$ \\
\hline S18 & (MH "Expectorants + ") \\
\hline
\end{tabular}


S17 TI ( steroid* or corticosteroid ${ }^{\star}$ or corticoid ${ }^{\star}$ or glucocorticoid ${ }^{\star}$ or cortison ${ }^{\star}$ or prednisone or prednisolone or hydrocortisone ) or AB ( steroid ${ }^{\star}$ or corticosteroid* or corticoid $^{\star}$ or glucocorticoid ${ }^{\star}$ or cortison* or prednisone or prednisolone or hydrocortisone )

\begin{tabular}{|c|c|}
\hline S16 & (MH "Adrenal Cortex Hormones+") \\
\hline S15 & (MH "Steroids") \\
\hline S14 & (MH "Nebulizers and Vaporizers") \\
\hline S13 & $\begin{array}{l}\text { TI ( inhaler* or nebuliser* or nebulizer* or bronchodilator }{ }^{\star} \text { or vaporiser }^{\star} \text { or vaporizer }^{\star} \text { ) or AB ( in- } \\
\text { haler* or nebuliser }{ }^{\star} \text { or nebulizer* or bronchodilator } \text { or vaporiser }^{\star} \text { or vaporizer }^{\star} \text { ) }\end{array}$ \\
\hline S12 & TI beta agonist* or $A B$ beta agonist ${ }^{\star}$ \\
\hline S11 & (MH "Adrenergic Beta-Agonists") \\
\hline S10 & (MH "Albuterol") \\
\hline S9 & $\begin{array}{l}\text { TI ( salbutamol or albuterol or ventmax or ventolin or volmax or airomir or asmasal or salamol or } \\
\text { salbulin ) or AB ( salbutamol or albuterol or ventmax or ventolin or volmax or airomir or asmasal or } \\
\text { salamol or salbulin ) }\end{array}$ \\
\hline S8 & S4 not S7 \\
\hline S7 & S5 or S6 \\
\hline S6 & (MH "Antibiotics+") \\
\hline S5 & (MH "Vaccines+") \\
\hline S4 & $\mathrm{S} 1$ or $\mathrm{S} 2$ or $\mathrm{S} 3$ \\
\hline S3 & $\mathrm{TI}\left(\right.$ whoop* or pertus $^{\star}$ ) or $\mathrm{AB}$ ( whoop* or pertus ${ }^{\star}$ ) \\
\hline S2 & (MH "Bordetella Pertussis") \\
\hline S1 & (MH "Whooping Cough") \\
\hline
\end{tabular}

\section{Appendix 3. AMED search strategy}

whoop $^{\star}$ or pertus ${ }^{\star}$

\section{Appendix 4. LILACS search strategy}

1. whoop $\$$ or pertus $\$$

2. estud\$ or clin\$ or grupo $\$$

3. 1 and 2

\section{Appendix 5. Search strategy, Pillay 2003}

MEDLINE was searched using the following search strategy. Search date: June 2003

1 exp WHOOPING COUGH/

$2 \exp$ BORDETELLA PERTUSSIS/

3 whooping.mp. (mp=title, abstract, cas registry/ec number word, MeSH subject heading] 
4 pertussis.mp. (mp=title, abstract, cas registry/ec number word, MeSH subject heading)

5 or/ $1-4$

6 exp VACCINES/

7 exp ANTIBIOTICS/

8 or/6-7

95 not 8

10 RANDOMIZED CONTROLLED TRIAL.pt.

11 CONTROLLED CLINICAL TRIAL.pt.

12 RANDOMIZED CONTROLLED TRIALS.sh.

13 RANDOM ALLOCATION.sh.

14 DOUBLE BLIND METHOD.sh.

15 SINGLE-BLIND METHOD.sh.

16 or $/ 10-15$

17 (ANIMAL not HUMAN).sh.

1816 not 17

19 CLINICAL TRIAL.pt.

20 exp Clinical Trials/

21 (clin\$ adj25 trial\$).ti,ab.

22 ((singl\$ or doubl\$ or trebl\$ or tripl\$) adj25 (blind\$ or mask\$)).ti,ab.

23 PLACEBOS.sh.

24 placebo\$.ti,ab.

25 random\$.ti,ab.

26 or $/ 19-25$

2726 not 17

2818 or 27

299 and 28

Additional information was identified in EMBASE using a similar search strategy. Search date: June 2003

LILACS was searched using the following search terms:

Whooping Cough OR Pertussis OR Bordetella OR Respiratory

Search date: November 2001

WHAT'S NEW

\begin{tabular}{lll}
\hline Date & Event & Description \\
\hline 30 January 2014 & New search has been performed & $\begin{array}{l}\text { We updated our searches and included two new studies: one } \\
\text { double-blind, randomised, placebo-controlled trial of mon- }\end{array}$ \\
\hline
\end{tabular}




\begin{tabular}{|c|c|c|}
\hline Date & Event & Description \\
\hline & & $\begin{array}{l}\text { telukast (Wang 2014), and one single-blind, randomised trial of } \\
\text { tramadol (Ghaffari 2011). Wang } 2014 \text { recruited a subgroup of } 70 \\
\text { participants with laboratory-confirmed pertussis. Ghaffari } 2011 \\
\text { recruited } 60 \text { participants with clinically diagnosed pertussis. Nei- } \\
\text { ther of these studies reported data in sufficient detail for analy- } \\
\text { sis. Kay Wang took on the roles of lead author and contact au- } \\
\text { thor. }\end{array}$ \\
\hline 30 January 2014 & $\begin{array}{l}\text { New citation required but conclusions } \\
\text { have not changed }\end{array}$ & $\begin{array}{l}\text { Our data analyses remain unchanged, as neither of the new tri- } \\
\text { als we included reported suitable data for further analysis of pre- } \\
\text { specified outcomes. }\end{array}$ \\
\hline
\end{tabular}

\section{HISTORY}

Protocol first published: Issue 4, 2001

Review first published: Issue 4, 2003

\begin{tabular}{|c|c|c|}
\hline Date & Event & Description \\
\hline 12 January 2012 & $\begin{array}{l}\text { New citation required but conclusions } \\
\text { have not changed }\end{array}$ & Kay Wang joined the authors to update this review. \\
\hline 12 January 2012 & New search has been performed & $\begin{array}{l}\text { Searches updated. No new studies identified as being suitable } \\
\text { for inclusion in this review. }\end{array}$ \\
\hline 9 April 2009 & New search has been performed & $\begin{array}{l}\text { Searches conducted. We included one trial since the review was } \\
\text { first published in } 2003 \text {. }\end{array}$ \\
\hline 9 April 2009 & $\begin{array}{l}\text { New citation required but conclusions } \\
\text { have not changed }\end{array}$ & $\begin{array}{l}\text { A new team of review authors took over and updated this review } \\
\text { in } 2009 .\end{array}$ \\
\hline 7 July 2008 & Amended & Withdrawn Issue 4, 2004. \\
\hline 11 April 2008 & Amended & Converted to new review format. \\
\hline 9 June 2003 & New search has been performed & Searches conducted. \\
\hline
\end{tabular}

\section{CONTRIBUTIONS OF AUTHORS}

Silvana Bettiol, Kay Wang, Matthew Thompson and Nia Roberts participated in study selection, data extraction and analysis. KW led the writing of the updated review in 2014. All authors contributed comments and edits.

\section{DECLARATIONS OF INTEREST}

Kay Wang, Rafael Perera and Anthony Harnden were investigators in a double-blind randomised controlled trial of montelukast for the treatment of postinfectious cough in adults, a subgroup of whom had laboratory-confirmed pertussis infection (Wang 2014). The trial was funded by the National Institute for Health Research (NIHR) School for Primary Care Research. Kay Wang was the Principal Investigator responsible for the day to day conduct of the trial, Rafael Perera oversaw the statistical analysis of trial data and Anthony Harnden was Chief Investigator of the trial. Some of the results from the trial are included in this review.

Matthew Thompson: no conflicts of interest to declare.

Carl Heneghan: no conflicts of interest to declare.

Nia Wyn Roberts: no conflicts of interest to declare.

Silvana Bettiol: no conflicts of interest to declare. 


\section{SOURCES OF SUPPORT}

\section{Internal sources}

- The Nuffield Department of Primary Care Health Sciences is part of the National Institute for Health Research (NIHR) School for Primary Care Research (SPCR), UK.

KW holds an NIHR Academic Clinical Lectureship. The views expressed in this paper are those of the authors and not necessarily those of the NHS, the NIHR or the Department of Health.

\section{External sources}

- No sources of support supplied

\section{N DEX TERMS}

\section{Medical Subject Headings (MeSH)}

Acetates [therapeutic use]; Albuterol [therapeutic use]; Anti-Inflammatory Agents [*therapeutic use]; Bordetella pertussis [immunology]; Cough [ ${ }^{\star}$ drug therapy] [etiology]; Dexamethasone [therapeutic use]; Diphenhydramine [therapeutic use]; Histamine H1 Antagonists [*therapeutic use]; Immunoglobulins [*therapeutic use]; Length of Stay; Quinolines [therapeutic use]; Randomized Controlled Trials as Topic; Whooping Cough [* ${ }^{*}$ complications] [drug therapy] [immunology]

\section{MeSH check words}

Adolescent; Adult; Child; Humans 